LA-8613-C

Conference

UC-97e

Issued: December 1980

\title{
Workshops to Rate
}

\section{and Assign Air and Water \\ Issues for Hydrothermal \\ Energy Development}

Joel M. Williams

Eugene M. Wewerka
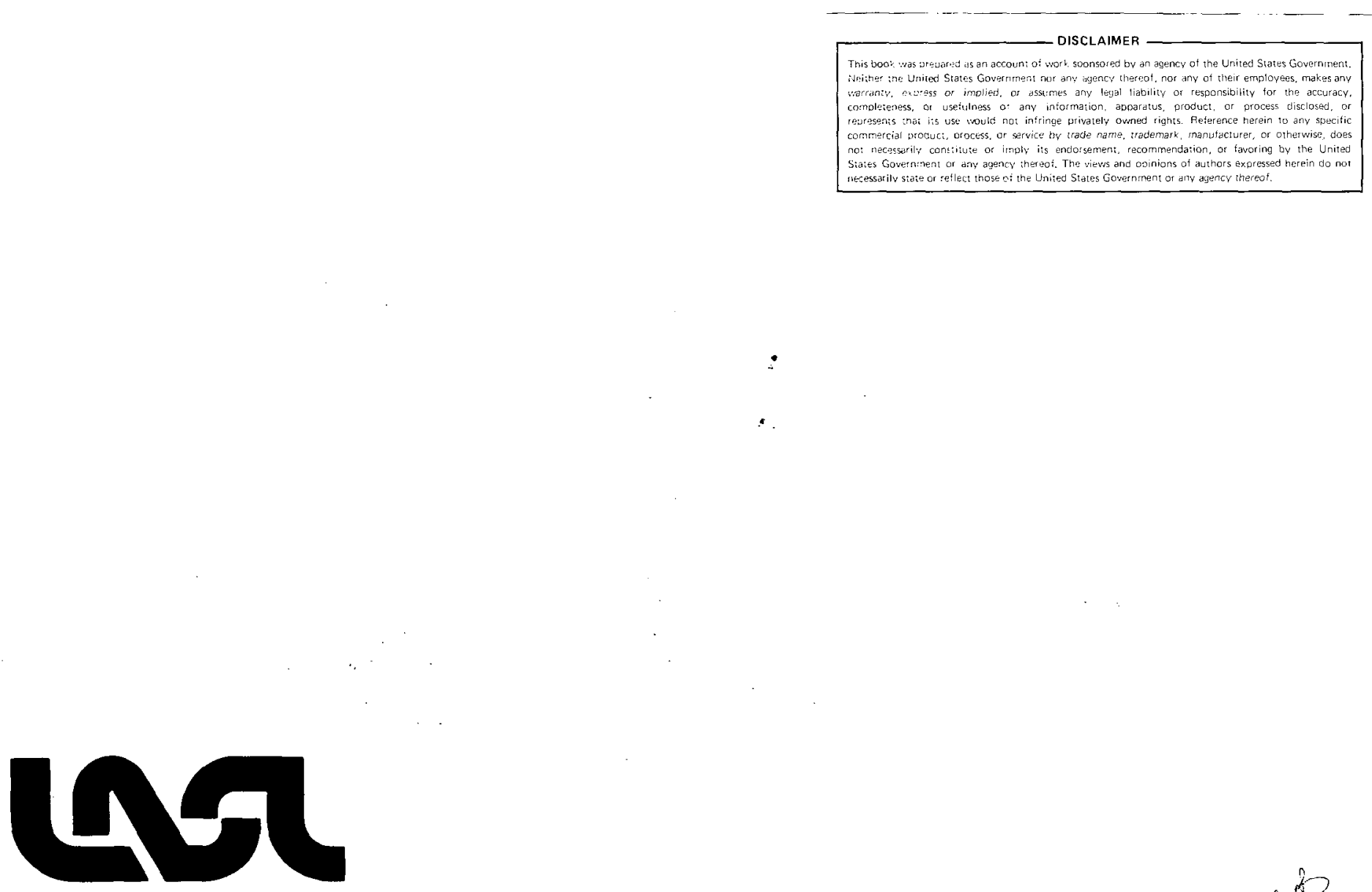


\section{DISCLAIMER}

This report was prepared as an account of work sponsored by an agency of the United States Government. Neither the United States Government nor any agency Thereof, nor any of their employees, makes any warranty, express or implied, or assumes any legal liability or responsibility for the accuracy, completeness, or usefulness of any information, apparatus, product, or process disclosed, or represents that its use would not infringe privately owned rights. Reference herein to any specific commercial product, process, or service by trade name, trademark, manufacturer, or otherwise does not necessarily constitute or imply its endorsement, recommendation, or favoring by the United States Government or any agency thereof. The views and opinions of authors expressed herein do not necessarily state or reflect those of the United States Government or any agency thereof. 


\section{DISCLAIMER}

Portions of this document may be illegible in electronic image products. Images are produced from the best available original document. 
CONTENTS

page

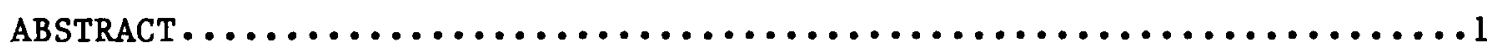

INTRODUCTION ............................................

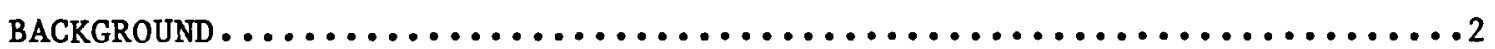

WORKSHOP ON ENVIRONMENTAL ISSUES ASSOCIATED WITH

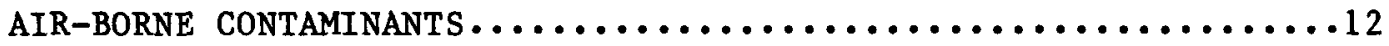

I. PRELUDE...................................... 12

II. DIGEST OF THE PRESENTATIONS ....................... 13

A. Hydrothermal Technology and the Baca Plant Siting 13

B. Pollutant Sources and Characterization $\quad 14$

C. Pollutant Transport 15

D. Environmental Impacts 16

E. Human Health Impacts 17

III. DISCUSSION GROUP SUMMARIES ........................ . 17

$\begin{array}{ll}\text { A. Source Characterization and Analysis } & 18\end{array}$

B. Pollutant Transport and Dispersion 20

C. Environmental Impacts 23

D. Human Health Impacts

IV. AIR-RELATED PROBLEMS . . . . . . . . . . . . . . . . . . . . . 27

WORKSHOP ON ENVIRONMENTAL ISSUES ASSOCIATED WITH

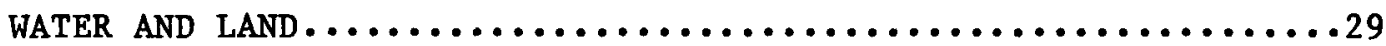

I. PRELUDE...........................................29

II. CURRENT ACTIVITIES BRIEFING........................... 29

III. ISSUE CONSIDERATIONS AND PRIORITIES................... 30

RESEARCH PRIORITIES AND RECOMMENDATIONS..........................

\section{APPENDIXES}

A INVITATION AND AGENDA FOR AIR-BORNE CONTAMINANTS WORRSHOP......36

B ATTENDEES TO LASL HYDROTHERMAL AIR-BORNE CONTAMINANTS WORKSHOP ..40

C DISCUSSIONS IN THE AIR-BORNE CONTAMINANTS WORKGROUPS . . . . . . . . 42

D INDIVIDUAL RESPONSES TO THE QUESTION OF THE MOST PRESSING, AIR-RELATED ISSUE FOR HYDROTHERMAL DEVELOPMENT. . . . . . . . . . . 45

E FOLLOW-UP LETTER TO AIR-BORNE CONTAMTNANTS WORKSHOP . . . . . . . . 53

F PARTICIPANTS IN THE LASL/LLL WATER/TERRESTRIAL WORKSHOP........55 


\author{
WORKSHOPS TO RATE AND ASSIGN AIR AND WATER ISSUES
}

FOR HYDROTHERMAL ENERGY DEVELOPMENT

Joe1 M. Williams and Eugene M. Wewerka

\begin{abstract}
$\underline{\text { ABSTRACT }}$
This report briefly describes the presentations, discussions, and recommendations associated with a semiformal, 2-day workshop organized and hosted by Los Alamos Scientific Laboratory personnel at Los Alamos, NM, from March, 11-12, 1980, and an informa1, 2-day workshop hosted by Lawrence Livermore Laboratory at Livermore and Konocti Harbor, CA, from April 15-16, 1980. These workshops were not conducted to determine what the problems are, but rather to determine which ones should be addressed and who should address them. Brief reviews of issues identified by previous workshops and studies are included as background.
\end{abstract}

\title{
INTRODUCTION
}

The development of liquid-dominated (hydrothermal) resources for the generation of electricity is in its infancy. Large scale utilization has not been technically demonstrated in the United States, and environmental constraints could be a limiting feature in achieving commercialization of this energy source. Resolution of potentially, but not identified, environmental constraints is a major goal of the Department of Energy to provide a reasonable pathway for full scale use of this national resource.

The Department of Energy (DOE) and its industrial co-partners (Union Geothermal and Public Service Co. of New Mexico) have concluded a contractual agreement to conduct a demonstration of liquid-dominated hydrothermal power in the Jemez Mountains of northern New Mexico. This demonstration will provide a major focal point for joint 
federal-industrial exploration of the technology and understanding of the environmental implications attendant to it.

The DOE through the Assistant Secretary for the Environment (ASEV) has asked the Los Alamos Scientific Laboratory (LASL) to assume the lead role in conducting a generic assessment of the environmental readiness of the liquid-dominated hydrothermal technology. This request asks LASL to assess the current environmental, health, and social acceptability of the generation of electricity from liquid-dominated resources, to identify potential environmental, health, or social impediments to the rapid development of hydrothermal resources, and to suggest environmental control strategies for removing or mitigating such impediments.

\section{BACKGROUND}

Many issues have been raised about potentially unfavorable environmental impacts from geothermal power production. Weekly news items can be found in local and state newspapers. These reflect a wide range of concerns, including water loss and pollution, foul smelling air, scenic destruction, and religious encroachment. Town meetings, such as the one in Los Alamos, NM on March 6, 1980, have been called to raise scientifically sound questions and to voice emotional and religious convictions.

The Geysers-Calistoga steam-dominated, Known Geothermal Resource Area (KGRA) in north central California has been the prime source of information about the impacts of geothermal development. A preliminary assessment of the environmental issues for that area, which accounts for about one-third of the geothermal energy produced in the world, has been made in an extensive set ( 8 volumes) of reports produced in 1978.* That set is the product of the Geothermal Overview Project, established at Lawrence Livermore Laboratory (LLL) by DOE/ASEV, and its many task

\footnotetext{
*"An Environmental overview of Geothermal Development: The Geysers-Calistoga KGRA," Vols 1 to 8 by members of the DOE/LLL Geothermal Overview Project Staff, UCRL-52496, 1978.
} 
groups and workshops. The issues and recomendations set forth by that effort are listed in Display $I$.

Several major workshops have been dedicated to the impacts of geothermal development on the environment. One workshop was held in Oakland, CA from October 11-12, 1978 by LLL for DOE/Division of Environmental Control Technology and was attended by 80 people. That workshop stressed compliance with environmental regulations at the plant site rather than environmental impacts on the surrounding areas. The abbreviated recommendations from that workshop are given in Display II as they were presented in the written documentation summarizing the workshop.*

A second workshop was held in Albuquerque, NM from September 7-8, 1979 by the New Mexico Energy Institute and the New Mexico Environmental Institute at New Mexico State University. The contributions of 60 individuals and a dozen groups were summarized in a preprogram draft. The completed documentation of the workshop and its recommendations and conclusions are currently being published." A list of the recommendations of that workshop is given in abbreviated form in Display III.

In addition to workshops, the readiness, development, and impact documentations required by law have been produced. The readiness document (DOE/ERD-0005) was produced in September, 1978 and was summarized in January, 1979 (DOE/ERD-0022). A list of the major environmental concerns noted in that document is presented in Display

\footnotetext{
*John H. Hill and Paul L. Phelps, "Workshop on environmental control technology for the Geysers-Calistoga KGRA," UCRL-47887, LLL, January 28,1980 .
}

\#Martha A. Byrant, Arlene H. Sharkey, and William A. Dick-Peddie, "Workshop for an Environmental Overview for the Development of Geothermal Resources in the State of New Mexica," NM Energy Institute and NM Environmental Institute under LLL/DOE/ASEV subcontract \# 4090109, draft final report, in press. 
DISPLAY I.

\section{Recommendations by the LLL Geothermal Overview Project for Research and Assessment Needs for Geothermal Resources in the Geysers-Calistoga KGRA. ${ }^{a}$}

\begin{tabular}{|c|c|}
\hline Issues & Recomendations \\
\hline \multicolumn{2}{|l|}{ High Priority } \\
\hline Control of hydrogen sulfide emissions & $\begin{array}{l}\text { - Development of abatement technology } \\
\text { - Studies to predict pollution } \\
\text { - Emission measurements } \\
\text { - Meteorological measurements } \\
\text { - Model development } \\
\text { - Model validation and prediction } \\
\text { - Air quality monitoring }\end{array}$ \\
\hline Noise control & $\begin{array}{l}\text { - Development of abatement technology } \\
\text { - Noise from venting strenm(?) wells } \\
\text { - Drilling noise } \\
\text { - Studies to predict noise }\end{array}$ \\
\hline Land-use conflicts & $\begin{array}{l}\text { - Forecasts of geothermal energy development } \\
\text { - Characterization of current land-use } \\
\text { - Analysis of land-use conflicts }\end{array}$ \\
\hline Landslides and soil erosion & $\begin{array}{l}\text { - Study of slope stability and geological hazarda } \\
\text { - Mapping of fault } \\
\text { - Studies of accelerated soil erosion } \\
\text { - Study of rock mechanics } \\
\text { - Assessment of regional geology }\end{array}$ \\
\hline Rare and endengered species & $\begin{array}{l}\text { - Study of rare plants in the region } \\
\text { - Study of peregrine faicon habitat } \\
\text { - Habitat studies of species of special concern }\end{array}$ \\
\hline \multicolumn{2}{|l|}{ Medium Priority } \\
\hline Data and information storage & - Establishment of a centralized data base \\
\hline Effects of hydrogen sulfide on agriculture & $\begin{array}{l}\text { - Chronic effects of low levels of hydrogen sulfide } \\
\text { on wine grapes and orchard crops } \\
\text { - Literature search. effects of hydrogen sulfide on wine quality }\end{array}$ \\
\hline Long term effects on the ecosystem & $\begin{array}{l}\text { - Collection of baseline data } \\
\text { - Ecosystem monitoring }\end{array}$ \\
\hline Fiscal impacts & $\begin{array}{l}\text { - Analysis of demand of public service } \\
\text { - Study of regions! revenue }\end{array}$ \\
\hline Effects of cooling tower drift & $\begin{array}{l}\text { - Emission and transport studies } \\
\text { - Studies of ecological effects }\end{array}$ \\
\hline Economic impacts & - Analysis of economic trends \\
\hline Demographic impacts & $\begin{array}{l}\text { - Analysis of demographic trends } \\
\text { - Analysis of the quality of life }\end{array}$ \\
\hline Degradation of groundwater and hot springs & $\begin{array}{l}\text { - Study of potable groundwater resources } \\
\text { - Study of hot springs }\end{array}$ \\
\hline \multicolumn{2}{|l|}{ Low Priority } \\
\hline Effects of hydrogen sulfide on health & $\begin{array}{l}\text { - Studies of the effects of chronic exposure on behavior } \\
\text { - Epidemiologic studies }\end{array}$ \\
\hline Accidental spills & - Monitoring \\
\hline Water resources management & - Study of water and waste disposal requirements \\
\hline Particulate emissions & - Analysis of particle composition \\
\hline Subsidence and seismicity & $\begin{array}{l}\text { - Subsidence studies } \\
\text { - Analyais of regional sensitivity } \\
\text { - Monitoring studies } \\
\text { - Seismic monitoring studies }\end{array}$ \\
\hline Weather modification & - Research survey \\
\hline
\end{tabular}

'Taken from "An Environmental Overview of Geothermal Development: The Geysers-Calistoga KGRA," vol.1, 1978. 
DISPLAY II.

\section{Summary of Recommendations from the Workshop on Environmental Control Technology for the Geysers-Calistoga KGRA ${ }^{a}$}

- Develop a coating to protect the well casing from erosion during air drilling.

- Develop better techniques for cement emplacement.

- Set up a program to test candidate cements under simulated and actual operating conditions.

- Develop a down-hole safety valve to use on wells installed in landslide areas.

- Improve knowledge of $\mathrm{H}_{2} \mathrm{~S}$ partitioning in conden. sers.

- Encourage development of alternative methods of $\mathrm{H}_{2} \mathrm{~S}$ abatement.

- Install berm and sump systems to contain spills on all power plants.

- Develop automatic control systems for the liquid portion of liquid handling systems.

- Strenghten the Liquid Waste Hauler law to include equipment checks, driver certification, and fines for substandard or defective equipment.

- Develop a muffler for steam venting at the wellhead.

- Develop a dynamic computer model to aid in designing automatic controls for steam-gathering systems.

- Allow time to develop and test processes before changing regulations.

- Carefully weigh the hazards and benefits introduced with abatement processes.

${ }^{a}$ Taken from the abstract of the report by John H. Hill and Paul L. Phelps entitled "Workshop on Environmental Control Technology for the Geysers-Calistoga KGRA," UCRL-52887, January 28, 1980. 


\section{DISPLAY III.}

\section{Ranking of Environmental Impacts Associated with Geothermal Development in New Mexico by the NMEI Workshop. ${ }^{a}$}

\section{HIGH PRIORITY IMPACT AREAS}

- Water supply and quality

- Air release of contaminants

- Socio-economic impacts

\section{LOW PRIORITY IMPACT AREAS}

- Biota

- Geophysics (seismicity, subsidence, and soil modification)

- Noise

${ }^{a}$ Taken from the ratings given in "Environmental Overview for the Development of Geothermal Resources in the State of New Mexico," by Martha A. Byrant, Arlene H. Starkey, and William A. Dick-Peddie, New Mexico Energy and Environmental Institutes at the New Mexico State University, draft final report, in press. 
IV. The environmental development plan (DOE/EDP-0036) was produced in August, 1979 and included an expanded list of environmental, health, and safety concerns. A list of these concerns and measures or requirements needed to address them is given in Display $V$. The final environmental impact statement, complete with public hearings and testimony, was released in January, 1980 (DOE/EIS-0049). The major potential impacts identified are summarized in Display VI.

The environmental concerns identified by the foregoing efforts contain items pertinent to general industrial development, such as terrestrial, ecological, socioeconomic, and cultural disturbances. Many of these are political or religious in nature and are not likely to be resolved by scientific efforts, except indirectly. Items of special concern to the hydrothermal industry include pollutant releases to the atmoshere and water systems, water resource depletion, noise, and seismicity. These industry-specific items (and several of the general group) are amenable to scientific treatment and often form the only solid reasons for public resistance to opening or expanding industrial facilities.

The environmental concerns for hydrothermal energy have been hammered out fairly well. The time has come to decide what to work on and who will do it. To this end LASL convened two limited-participant workshops. 


\section{DISPLAY IV.}

\section{Major Environmental Concerns Attendant to Hydrothermal Energy as Identified in the Environmental Readiness Document. ${ }^{\text {" }}$}

- Fugitive airborne emissions and objectionable odor are present from all conversion cycles.

- Effluents from cooling tower drifts may affect local ecology and human health.

- Waterborne effluents, spent brine (direct flash and binary cycle techniques), and binary fluids will require great care during disposal.

- High noise levels, particularly with the dry steam cycle, have been found to be objectionable.

- Possible enhanced siesmicity can result from either extraction or reinjection of subterranean brine.

- Water requirements for cooling towers may pose conflicts.

- Land use and associated socioeconomic effects may pose difficulties as most resources are located in thinly populated, semiarid areas in the United States.

"Taken from the "Environmental Readiness of Emerging Energy Technologies - Summary Report," DOE/ERD-0022, January, 1979. 
DISPLAY V.

\section{Environmental, Health, and Safety Concerns and Requirements for Hydrothermal Energy Systems. ${ }^{a}$}

\begin{tabular}{|c|c|c|}
\hline EH\&S Concern & $\begin{array}{c}\text { EHas } \\
\text { Research Area } \\
\end{array}$ & EH\&S Requirement: \\
\hline \multicolumn{3}{|l|}{ 1. Release of Airborne Effluents } \\
\hline \multirow[t]{5}{*}{$\begin{array}{l}\text { Hydrothermal fluids typically contain a number } \\
\text { of compounds such as } \mathrm{CO}_{2}, \mathrm{NH}_{3}, \mathrm{H}_{2} \mathrm{~S}, \mathrm{CH}, \mathrm{Rn}, \mathrm{Hg} \text {, and } \mathrm{B} \text {. } \\
\text { These and other chemicals such as salts in cooling } \\
\text { tower drift may be released to the atmosphere; } \\
\text { impacts may occur on local ecosystems and on human } \\
\text { health. } \mathrm{H}_{2} \mathrm{~S} \text { is of particular concern because of its } \\
\text { disagreeable odor (above } 5 \text { ppb) and toxic effects } \\
\text { (above } 20 \mathrm{ppm} \text { ). }\end{array}$} & $\begin{array}{l}\text { Characterization } \\
\text { and Measurement }\end{array}$ & $\begin{array}{l}\text { 1.1. Identify and measure the levels of } \\
\text { effluents that may be discharged during } \\
\text { exploration, development, and utilization. } \\
\text { 1.2. Establish baseline and monitoring networks } \\
\text { for the most significant effluents, and } \\
\text { develop new instrumentation as needed. }\end{array}$ \\
\hline & $\begin{array}{l}\text { Physical and } \\
\text { Chemical Effects }\end{array}$ & $\begin{array}{l}\text { 1.3. Develop models necessary to predict the transport, } \\
\text { diffusion, and transformatiom of pollutants } \\
\text { in complex terrain. }\end{array}$ \\
\hline & $\begin{array}{l}\text { Health and } \\
\text { Ecological Effects }\end{array}$ & $\begin{array}{l}\text { 1.4. Develop dose-response data for effects on native } \\
\text { and agricultural ecosystems and on human } \\
\text { health. }\end{array}$ \\
\hline & $\begin{array}{l}\text { Environmental } \\
\text { Evaluations }\end{array}$ & $\begin{array}{l}\text { 1.5. Assess the potential effects of effluent } \\
\text { releases within a regional context for full-scale } \\
\text { development, and develop environmental design } \\
\text { criteria. }\end{array}$ \\
\hline & $\begin{array}{l}\text { Control } \\
\text { Technology }\end{array}$ & $\begin{array}{l}\text { 1.6. Develop control technologies as needed to meet } \\
\text { regulatory standards and environment } \\
\text { design criteria }\end{array}$ \\
\hline \multicolumn{3}{|l|}{ 2. Release of Waterborne Effuents } \\
\hline \multirow[t]{5}{*}{$\begin{array}{l}\text { Large volumes of spent geothermal huids and cooling } \\
\text { tower blowdown will be generated. They may contain } \\
\text { dissolved volstile compounds and large quantities } \\
\text { of dissolved solids. The concern is for long-term } \\
\text { disposal of such fluids so that beneficial sources } \\
\text { of water are protected. Treatment may be required } \\
\text { that results in solid waste generation. }\end{array}$} & $\begin{array}{l}\text { Characterization } \\
\text { and Measurement }\end{array}$ & $\begin{array}{l}\text { 2.1. Identify and measure the level of effluents } \\
\text { that may be discharged during exploration, } \\
\text { development, and utilization. } \\
\text { 2.2. Establish baseline and monitoring networks } \\
\text { for the most significant effluents, and } \\
\text { develop new instrumentation as needed. }\end{array}$ \\
\hline & $\begin{array}{l}\text { Health and } \\
\text { Ecological Effects }\end{array}$ & $\begin{array}{l}\text { 2.3. Develop dose-reaponse data for effects on } \\
\text { aquatic ecosystems and human health. }\end{array}$ \\
\hline & $\begin{array}{l}\text { Environmental } \\
\text { Evaluations }\end{array}$ & $\begin{array}{l}\text { 2.4. Assess the potential effects of effluent } \\
\text { releases within a regional context for full- } \\
\text { scale development, and develop environmental } \\
\text { design criteria. }\end{array}$ \\
\hline & & $\begin{array}{l}\text { 2.5. Assess the consequences of accidental releases } \\
\text { of effluents. }\end{array}$ \\
\hline & $\begin{array}{l}\text { Control } \\
\text { Technology }\end{array}$ & $\begin{array}{l}\text { 2.6. Develop control technologies (surface } \\
\text { and subsurface) as needed to meet regulatory } \\
\text { standards and environmental design criteria. }\end{array}$ \\
\hline \multicolumn{3}{|l|}{ 3. Noise } \\
\hline $\begin{array}{l}\text { Uncontrolled noise levels associated with exploration } \\
\text { and drilling, well venting and testing, and } \\
\text { operational processes can reach levels as high as } \\
120 \mathrm{dBA} \text { at the site boundary and may have } \\
\text { deleterious effects on human populations and local } \\
\text { fauna. }\end{array}$ & $\begin{array}{l}\text { Environmental } \\
\text { Evaluations and } \\
\text { Control Technology }\end{array}$ & $\begin{array}{l}\text { 3.1. Develop noise abatement technologies as needed to meet } \\
\text { noise ordinances and standards and environmental } \\
\text { design criteria. }\end{array}$ \\
\hline
\end{tabular}

${ }^{a}$ As identified in the Environmental Development Plan (DOE/EDP-0036). 


\section{DISPLAY V (contd).}

\section{Environmental, Health, and Safety Concerns and Requirements for Hydrothermal Energy Systems.}

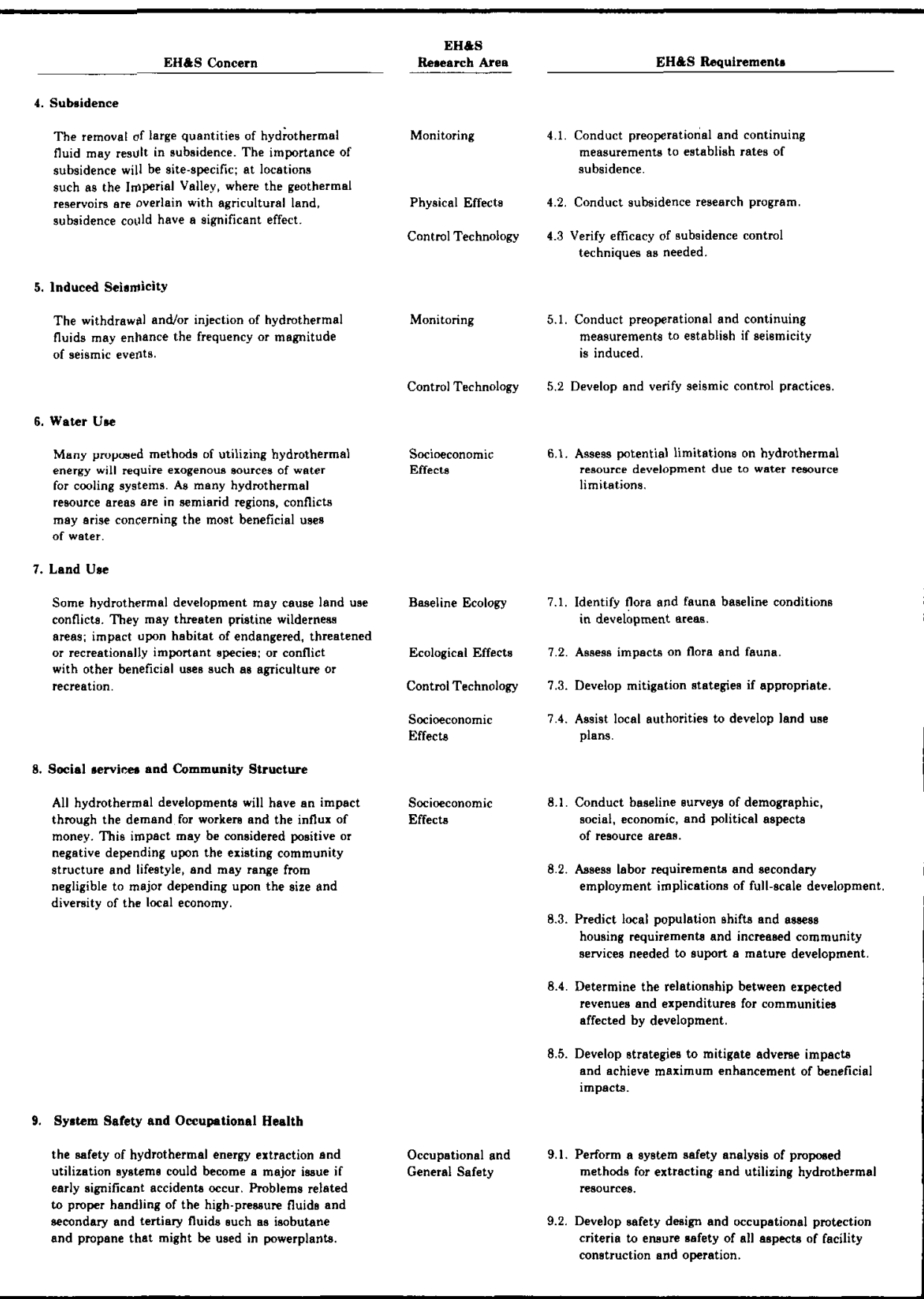




\section{DISPLAY VI.}

\section{Summary of Potential Impacts of Development of the 50-MWe Geothermal Well Field,}

Power Plant, and Transmission Lines at the Baca Site. ${ }^{\mathrm{a}}$

\begin{tabular}{|c|c|c|c|c|c|c|}
\hline Ecology & Land Une & Geology & Socioeconomics & Cultural Resources & Air & Water \\
\hline $\begin{array}{l}\text { - Disturbance of important } \\
\text { winter range }\end{array}$ & $\begin{array}{l}\text { - Grazing and logging } \\
\text { largely unaffected }\end{array}$ & $\begin{array}{l}\text { - Induced subsidence and } \\
\text { seimmicity are very unlikely }\end{array}$ & $\begin{array}{l}\text { - Minor effects of disassociation } \\
\text { between costs of services } \\
\text { and tax benefita }\end{array}$ & $\begin{array}{l}\text { - Potential impacts on identified } \\
\text { archeological sites }\end{array}$ & $\begin{array}{l}\text { - Impact of release of } \\
\leqslant 6 \text { gramesese }(50 \text { of } / \text { hr) } \\
\text { of hydrogen sulfide } \\
\text { during plant operation }\end{array}$ & $\begin{array}{l}\text { - Comaumptive water requirement } \\
\text { of plant (107 k/ } \mathrm{kg} / \mathrm{sec} \text { or } \\
820,000 \mathrm{lb} / \mathrm{hr} \text { ) requires } \\
\text { withdrawal of } \sim 5.67 \mathrm{ha}(14 \text { acres) } \\
\text { of land from irrigation over } \\
\text { the } 30 \text { year life of the plant }\end{array}$ \\
\hline $\begin{array}{l}\text { - Loss of habitat for Jemez } \\
\text { Mountain Salamander (state } \\
\text { endangered species) }\end{array}$ & $\begin{array}{l}\text { - Major recreation resources } \\
\text { affected (decreased accessability } \\
\text { and visual impact of transmisasion } \\
\text { corridora }\end{array}$ & & $\begin{array}{l}\text { - Potential impacts of increased } \\
\text { traffic volumes on Indian } \\
\text { Pueblos }\end{array}$ & $\begin{array}{l}\text { - Potentiai disruption or } \\
\text { desecretion of Indian religious } \\
\text { sites, sacred areaso of obeets } \\
\text { iplansts, animals, water, etc.) }\end{array}$ & $\begin{array}{l}\text { - Impact of release of } \\
\sim 0.22 \mathrm{~kg} / \mathrm{sec}(1900 \mathrm{l} / \mathrm{b} / \mathrm{hr} \text { ) of cooling } \\
\text { tower drift during plant operation }\end{array}$ & $\begin{array}{l}\text { - Geuthermal nuid withdrawul } \\
\text { will reduce the flow in the demez } \\
\text { River by } \sim 0.78 \text { litera/sec } \\
\text { (12.36 gal/min) }\end{array}$ \\
\hline $\begin{array}{l}\text { - Potential effects on rare } \\
\text { plant opecies }\end{array}$ & $\begin{array}{l}\text { - Potential threat to designated } \\
\text { National Natural Landmark }\end{array}$ & & & $\begin{array}{l}\text { - Potential interference with } \\
\text { access to Indian religious } \\
\text { sites, sacred areas, or collecting } \\
\text { grounds for sacred objects }\end{array}$ & & \\
\hline \multirow[t]{2}{*}{$\begin{array}{l}\text { - Increased stream sedimentation } \\
\text { and posaible damage to trout } \\
\text { fishery }\end{array}$} & $\begin{array}{l}\text { - Poasaible conflicte with future } \\
\text { public acquisition of the Baca } \\
\text { property }\end{array}$ & & & $\begin{array}{l}\text { - Potential interference with } \\
\text { Indian religious ceremonies }\end{array}$ & & \\
\hline & $\begin{array}{l}\text { - Estimated land requirements } \\
\text {-diaturbance for plant and } \\
\text { wells: } 18.2 \mathrm{ha} \text { (45 acres) } \\
\text { trtansmission tine right of } \\
\text { way: } \\
\text { +corridor } 1: \\
\quad 97.5-106.7 \mathrm{ha}(\sim 241-246 \text { acres) } \\
\text { +corridor } 2: \\
\text { 112.8-126.5 ha ( 279-.313 acres) }\end{array}$ & & & $\begin{array}{l}\text { - Withdrawal of Beothermal fuids } \\
\text { may effect discharge of Indian } \\
\text { sacred springs }\end{array}$ & & \\
\hline
\end{tabular}

a'Taken from the "Final Environmental Impact Statement - Geothermal Demonstration Plant, 50-MWe Power Plant -

Sandoval and Rio Arriba Counties, New Mexico," DOE/EIS-0049, January, 1980. 
WORKSHOP ON ENVIRONMENTAL ISSUES

ASSOCIATED WITH AIR-BORNE CONTAMINANTS

I. PRELUDE

The workshop was opened on March 11, 1980 by Eugene Wewerka of LASL, who had organized it and had invited the participants (see Appendixes $A$ and $B$ ). He set the tone of the meeting by stating that

\footnotetext{
- The basic issue is environmental readiness not regulation;
- Environmental issues are defined reasonably well already;

- Information needs should be defined; and
- Monitoring should be considered the responsibility of the company and not essential to whether the techology is ready or not.

Arthur Wilbur (DOE, Albuquerque, NM) presented his expectations for the workshop relative to his (DOE's) Hydrothermal Development Program (HDP) at the Baca location. The HDP is seeking to develop hydrothermal energy in an economically viable and environmentally acceptable manner that will smooth the way for later developments. The HDP is looking for solutions and he wanted the workshop to define the areas to be addressed and to set prlorities. Monftoring would be conducted primarily by the industrial co-partners through their subcontractor (WESTEC).

Frank Hudson (DOE/ASEV/OHER, Washington, DC) presented his expectations for the workshop relative to the ASEV funding which was to pay for the work set forth by the workshop. He pointed out clearly 
that the ASEV/OHER effort is not part of the Baca project, but will work as closely as possible to help bring hydrothermal energy on-line. He stressed that ASEV/OHER does not want arm waving, but does want solid data that will stand scrutinizing. This data is desired in 3 years, but monies lag behind capabilities. He wanted the workshop to determine what should be done by whom and when.

Dave Sabo of PNM spoke for the industrial co-partners and assured their willingness to cooperate in finding solutions to the impediments to hydrothermal energy development.

II. DIGEST OF THE PRESENTATIONS

\section{A. Hydrothermal Technology and the Baca Plant Siting}

Gary Langhorst of LASL presented a brief review of hydrothermal technology in which he compared and contrasted the Baca and Geysers operations. The principle difference in mechanics is the need in the liquid-dominated, Baca case to include a flasher to separate the steam driving fluid from the excess liquid. $\mathrm{H}_{2} \mathrm{~S}$ abatement is needed at both operations and three processes are being evaluated. The Baca liquid may have more $\mathrm{H}_{2} \mathrm{~S}$ (204ppmw) * than does the Geysers fluid (157ppmw)."

Felix Miera of LASL presented a brief documentary of the siting for the Baca plant. He emphasized the pristine nature of the complex, mountainous terrain, but pointed out that past logging practices have dramatically altered some of the mixed conifer slopes. Small streams that contain native and brown trout were illustrated. Wildife depicted in the area included elk, mule deer, coyotes, and mountain lions as well as numerous species of small mammals.

\footnotetext{
${ }^{*} \mathrm{DOE} / \mathrm{EIS}-0049, \mathrm{p} 3-56$.

\#Pimente1,K.D.; "An Environmental Overview of Geothermal Development: The Geysers-Calistoga KGRA," Vol. 6, Water Quality, LLL UCRL-52498, $\mathrm{p} 12,1978$.
} 


\section{B. Pollution Sources and Characterization}

John Evans of Battelle Pacific Northwest Laboratory (PNL) presented a review of the general chemistry of geothermal/hydrothermal fluids. Hydrogen sulfide, radon, and mercury were mentioned to occur at worrisome levels in the non-condensable gases. Most of the mercury is in the elemental form. The half-life for the oxidation of hydrogen sulfide was given as 12-15 hours. Boron, arsenic, ammonia, salt, heavy metals and silica were listed as the species of concern in the liquid brine. Evans pointed out the difficulty of sampling the cooling towers which have very nonuniform flows over them and, hence, the difficulty in evaluating the actual discharges of pollutants. The deposition of mercury and boron around a cooling tower was shown to fall off rapidly as the distance from the tower increased. High values in the top $2.5-\mathrm{cm}$ of soil within $10 \mathrm{~m}$ of the towers were 1000-3000 ppb for total mercury and $\sim 120$ ppm for leachable boron. Near background values (100 ppb for mercury and 0.2-0.7 ppm for boron) were generally found near the $100 \mathrm{~m}$ mark. The high, close-in deposition was attributed to the fallout of large drift droplets.

John Koranda of LLL presented data from the Geysers on the levels of boron in the circulating water from Units 1 to 11 and boron deposition around Unit 12. Boron in the circulating water of any given unit has increased with age. A moderate increase occurred in Units 1 to 4 from 1964 to 1970 (20 ppm boron going to $50 \mathrm{ppm}$ boron). When Units 5 to 8 came on line in 1972, they had boron levels close to those of Units 1 to 4 (40-110 ppm), but the levels rose dramatically until 1974 (110-350 ppm) at which time the rate of increase slackened considerably. After several years of slight climb, boron levels in the circulating waters of Units 9 to 11 were around $90 \mathrm{ppm}$ in 1977; values for Units 1 and 2 were comparable, while levels in Units 3 to 8 were between $170 \mathrm{pp} \underline{\text { m }}$ and $430 \mathrm{pp}$. Deposition of boron in a straight line away from Unit 12 on June 26,1979 was $545 \mu \mathrm{g} / \mathrm{m}^{2}$ at $41 \mathrm{~m}, 226 \mu \mathrm{g} / \mathrm{m}^{2}$ at $83 \mathrm{~m}$, and $142 \mu \mathrm{g} / \mathrm{m}^{2}$ at $120 \mathrm{~m}$. Cheesecloth samplers placed at the same points showed a similar trend: $162 \mu \mathrm{g}, 102 \mu \mathrm{g}$, and $72 \mu \mathrm{g}$ over a 14-day period. 
Lynn Anspaugh of LLL, as part of his health-effects presentation, presented data on contaminants in the steams at the Geysers. The levels of $\mathrm{H}_{2} \mathrm{~S}, \mathrm{Hg}, \mathrm{NH}_{3}$, and $\mathrm{B}$ removed during $\mathrm{H}_{2} \mathrm{~S}$ abatement at Unit 7 on December 14,1976 were $99.3 \%, 0 \%, 71 \%$, and $92 \%$, respectively. Unabated emissions in the Geysers are $1800 \mathrm{~g}$ of $\mathrm{H}_{2} \mathrm{~S}, 1540 \mathrm{~g}$ of $\mathrm{NH}_{3}, 26000 \mathrm{~g}$ of $\mathrm{CO}_{2}, \quad 0.01 \mathrm{~g}$ of $\mathrm{Hg}$, and $120 \mu \mathrm{Ci}$ of $\mathrm{Rn}$ per $\mathrm{MWe} \cdot \mathrm{h}$. Guidelines for $\mathrm{H}_{2} \mathrm{~S}$ are $50 \mathrm{~g} / \mathrm{MWe} \cdot \mathrm{h}$ (CARB after 1985) and $2 \mathrm{~g} / \mathrm{MWe} \cdot \mathrm{h}$ (USEPA proposed 1979). The $\mathrm{Hg}$ value is comparable to that for equivalent electricity produced by coal. The source of some benzene (150-650 ppm) in the non-condensible gases of the Imperial valley fluids is unknown.

Ralph Williams of PNM described their past and current efforts at monitoring $\mathrm{H}_{2} \mathrm{~S}$ levels and air parameters in the Baca area. Mobile $\mathrm{H}_{2} \mathrm{~S}$ monitors have been operated at Baca boundary locations along Sulfur Creek and at several locations futher down the Jemez River by Western Scientific Services, Inc. of Fort Collins, CO. PNM has run some balloon collecting experiments and has activated (March 1980) a 200-ft monitoring tower at the plant site in Redondo Canyon. WESTEC will be monitoring air quality at a high point halfway up the side of Redondo Border and on Redondo Border between Sulfur and Redondo Creeks on a line with the 200-ft tower. The monitors will help establish the baseline data on the abilities of the disturbed and undisturbed areas in the Baca to comply with the New Mexico 10ppb $\mathrm{H}_{2} \mathrm{~S}$ standard at the Baca boundary.

\section{Pollutant Transport}

Tom Kyle of LASL presented an informative description of the use of a new type of LIDAR (Light Detection and aaing) as a means of tracking plumes. This method tracks a dispersion of fluorescent particles by a computer driven LASER. The concentration and location of the particles are monitored by the fluorescent signal returned after a pulse of laser light is transmitted in the direction of the particles. Since the fluorescent signal is specific to the particles dispersed, plumes can be tracked over long distances. The method has a beam resolution of $50 \mathrm{~m}$ at $8 \mathrm{~km}$ and a lower detection limit of 10 
particles $/ \mathrm{cm}^{3}$ at $1 \mathrm{~km}$. This method is most promising for single location monitoring of air transport paths.*

Sumner Barr of LASL described the meteorological conditions in the Valle Grande Caldera region. The primary features are a significant easterly movement of air during the day and a drainage to the south through terrestrial valleys to the town of Jemez Springs at night. He also told of his participation in ASCOT (Atmospheric Studies of Complex Terrains) which is developing a model for airflow in terrains similar to that in the Valle Grande Caldera.

\section{Environmental Impacts}

Joe Shinn of LLL presented a wide variety of results that LLL has obtained on the influence of $\mathrm{H}_{2} \mathrm{~S}$ on plants. These results included weight gains and losses and photosynthesis rates for a wide range of $\mathrm{H}_{2} \mathrm{~S}$ concentrations. (The latter were measured with a special, backpackable, photosynthesis measuring device developed at LLL and capable of monitoring photosynthesis in both broadleaf and needle plants.) He also described a model which depicts the mass growth of plants under a variety of environmental conditions, including fire.

The siginificant feature of Shinn's presentation was evidence that fractional ppm levels of $\mathrm{H}_{2} \mathrm{~S}$ (100-200 pp ) are not detrimental in the acute sense to plant growth or photosynthesis, but instead actually stimulated growth. Increased honeybee lifespan was also noted. At $300 \mathrm{ppb} \mathrm{H}_{2} \mathrm{~S}$, however, plant crops (lettuce, sugar beets, alfalfa, and cotton) grew about $88 \%$ of normal and honeybee lifespan was shortened $50 \%$. When $50 \mathrm{ppm}$ of $\mathrm{CO}_{2}$ was included with the $300 \mathrm{ppb}$ of $\mathrm{H}_{2} \mathrm{~S}$ to simulate concurrent $\mathrm{CO}_{2}$ release at an operating geothermal plant, the crop growths were $114 \%$ of normal, but the honeybee lifespan was shortened $5 \%$ more. At least over the short span, plants are able to

* The release of mass-21 methane is also attractive. This method has been demonstrated by LASL to be capable of tracking transport from Idaho to New York by using a small release of tracer. 
correct for small $\mathrm{H}_{2} \mathrm{~S}$-induced growth reductions by higher rates of photosynthesis when higher $\mathrm{CO}_{2}$ levels are present.

\section{E. Human Health Impacts}

Lynn Anspaugh of LLL prefaced his presentation by stating that "geothermal energy is relatively benign if $\mathrm{H}_{2} \mathrm{~S}$ is abated". (Noise is a possible non-pollutant occupational problem.) He presented a list of possible air-borne contaminants $\left(\mathrm{H}_{2} \mathrm{~S}, \mathrm{NH}_{3}, \mathrm{CO}_{2}, \mathrm{~B}, \mathrm{~F}\right.$, hydrocarbons, mercaptans, $\mathrm{Hg}, \mathrm{As}, \mathrm{Se}, \mathrm{Rn}$, and particulates) and reports of occupational illnesses from 1974-1977. He concluded from these that only $\mathrm{H}_{2} \mathrm{~S}$ is likely to cause occupational problems for geothermal-related exposures. The NIOSH-recommended 1 imit is $10 \mathrm{ppm}$ for a 40-h week. This is below the eye-damaging level (50 ppm), but an order of magnitude $(10 \mathrm{x})$ above the New Mexico air standard (10 ppb ). The average human olfactory level is around $5 \mathrm{pp} \underline{\mathrm{b}}$. Some humans (alcoholics, psychotics, and those with respiratory and eye diseases) are sensitive at lower concentrations. Claims of detrimental health effects have been made at the Geysers and appear to be related to $\mathrm{H}_{2} \mathrm{~S}$ levels around $100 \mathrm{pp}$. Humans have a detoxification mechanism which combats $\mathrm{H}_{2} \mathrm{~S}$ accumulation in the body and thus reduces cumulative doses. Anspaugh presented evidence which suggests that geothermal energy production in California is displaying emerging industry problems in the area of illnesses. Thus there are about 200 occupational illnesses per 100000 people for the geothermal industry versus about 5 per 100000 for California as a whole. Most of the illnesses (skin dermatoses) are related to the $\mathrm{H}_{2} \mathrm{~S}$-abatement sludges. This high incidence level should fall in line with other industries as the geothermal industry solves its problems.

\section{DISCUSSION GROUP SUMMARIES}

The four discussion groups met sequentially to allow everyone to participate on each topic. Each leader of a discussion group prepared a summary of the questions, answers, suggestions, solutions, etc. 
which occurred in his group. An author-identified collection of some of the inputs taken as notes by J. M. Williams (LASL) is presented in Appendix $C$.

\section{A. Source Characterization and Analysis}

The following review was written by John C. Evans of PNL.

Source characterization of air pollutants is generally considered to be an important part of environmental impact assessment. It provides among other things the source term for transport and dispersion models. During the workshop deliberations, a number of problems were discussed concerning the adequacy of existing source characterizations procedures. Species which have been measured extensively at a wide variety of geothermal sites include $\mathrm{H}_{2} \mathrm{~S}, \mathrm{~B}, \mathrm{NH}_{3}, \mathrm{~F}, \mathrm{Cl}$, As, $\mathrm{Hg}, \mathrm{CH}_{4}, \mathrm{CO}_{2}, \mathrm{SO}_{2}$, and major, minor, and trace elements. Benzene has been detected at several sites and should be included in future measurements. Other hydrocarbons and mercaptans should also be measured. Sulfate in cooling tower drift is another source term which requires better characterization. A good deal of discussion was given to the subject of cooling tower drift. Better techniques are needed for measuring the total quantities of drift emitted from various types of cooling towers. There is also very little information available on the composition of cooling tower drift. It was noted, however, that boron emissions from cooling tower drift have been observed to have impact on vegetation at the Geysers over only a very limited area. Boron is not expected to have a major importance at the Baca 
project or on similar hydrothermal projects since boron tends to remain in the brine phase of a liquid-dominated system.

Most of the remaining discussion focused on the $\mathrm{H}_{2} \mathrm{~S}$ problem. It was pointed out that ambient air-quality standards for New Mexico ( 10 ppbv) are very near or below the state-of-the-art detection limit for routine monitoring. It thus appears that some type of source term characterization combined with an ASCOT-type dispersion model is very important, particularly at the Baca site. Material balance studies are not wholly adequate for this purpose since for $\mathrm{H}_{2} \mathrm{~S}$ they tend to overestimate the emissions. It was generally agreed that the gas flow patterns in cooling tower exhausts are very complex and that as a result the types of limited scale measurements which have been carried out to date are quite inaccurate. I feel, however, that the negative aspects of this situation were perhaps overemphasized in the discussion. It is perfectly possible to accurately characterize $\mathrm{H}_{2} \mathrm{~S}$ emissions from a geothermal plant provided a sufficiently large effort is carried out. The need for this has not been strong enough in the past. An extensive effort of this sort, however, was carried out about two months ago at the Geysers Unit 15 as a joint effort between PG\&E and PNL. An instrumented, movable scaffold was constructed over one of the cells of the cooling tower. The $\mathrm{H}_{2} \mathrm{~S}$, airflow, temperature, and aerosol profiles were carefully mapped at a large number of points traversing the cooling tower stack. The whole assembly was rotated $90^{\circ}$ and the procedure repeated. This was done on two of the five cells. These data have not been fully digested yet, at least at PNL, but the method certainly appears to be feasible for 
obtaining accurate source term information. It was generally agreed during the workshop discussion that this type of approach should be used in the future when the data are to be used as modeling inputs. The Baca project should provide an ideal situation for fully exploring this method. At least on one occasion all of the cooling tower cells should be sampled with full transverses at several angles. These measurements should be reported on a number of occasions on one cell to assess temporal variations. The ultimate goal of this work would be to provide a basis for relating limited $\mathrm{H}_{2} \mathrm{~S}$ concentration measurements at single points to total emissions and to accurately assess the uncertainties involved. The level of effort required, while quite a bit greater than is normally involved in sampling, is still relatively modest.

\section{B. Pollutant Transport and Dispersion}

The following review was written by Sumner Barr and Tom Kyle of LASL.

Atmospheric transport and turbulent diffusion of aif-borne effluents represents one of the more serious unsolved problems in assessing the environmental consequences of geothermal energy development. Many geothermal sites, including the Baca site, are located in areas of hhghly complex topography and the conventional techniques for estimating the trajectories and dilution of pollutants are generally inadequate for these settings. The workshop participants agreed on the need to develop more refined methods for modeling 
transport in complex terrain environments and for measurements of meteorology and air quality parameters in highly time/space variable fields, often with limited accessability.

In formulating a program of environmental research for geothermal activities, we must make use of the generalized capabilities that exist within the DOE in particular and the scientific community at large. One such resource is the ASCOT (Atmospheric Studies in Complex Terrain) program which is supported by the DOE/ASEV and is aimed at documenting and modeling terrain-influenced airflow and turbulence phenomena in a generalized sense. The program is a multilaboratory effort that utilizes a balance of theory, field experiments, and modeling to develop methods for estimating transport effects in a variety of topographic settings.

ASCOT is not directed at any particular energy technology, but is a resource available to the scientific staff of a technology-based study team. Data and models are available from the program. Manpower for model development or field measurements might be available to a site study if the site were to fit the current needs of the ASCOT program. Generally, however, a technology-based assessment should be formulated to supply its own needed data and to maintain a close liaison with generic programs such as ASCOT.

Models as a tool for estimating atmospheric transport and diffusion were of considerable interest to workshop participants. Models are used in practice to:

- Plan a technology development including plan, and siting and process selection; 
- Design operating facilities and pollution abatement; and

- Design air-quality monitoring networks and interpret the data collected.

The group expressed concern regarding the confidence limits that could be placed on models. As the confidence in model verification increases they can be extremely valuable in avoiding conservative overdesign of pollution abatement equipment and in designing more cost-effective air-quality monitoring networks. Models are the tools that allow the step from emissions to ambient air quality and environmental effects. In some cases acceptable emission control methods have been based on the monitoring of critical meteorological paramenters, implying a high confidence level on the part of the regulatory agency in the model that translated the parameters to an air quality estimate.

Since vegetative cover is an important part of the setting, its role was pursued by the workshop. Vegetation can play an active role in the dynamics of some transport scenarios, but more generally it will be the pollutant receptor. An example of a dynamic influence is the frictional retardation of shallow noctural slope winds by trees that may represent $20-50 \%$ of the depth of the flow system. When vegetation is the receptor of a pollutant, the mechanisms of turbulent flux through the canopy layer is a factor as well as the complex questions dealing with the mechanisms of deposition and plant uptake. This highly specialized area is one for 
which the geothermal assessment study should rely on related research through liaison rather than attempt to perform research within the program.

The role of remote sensing techniques was explored as an alternative to expensive in situ monitoring stations. Also, tracers were discussed as a means of empirically estimating plume behavior and for delineating contributions from different sources. Remote sensing is not currently an accepted substitute for compliance monitoring, although as a research tool, it is valuable. Tracers should be exploited for a variety of practical and research purposes in the geothermal environmental programs.

There was general agreement of the need for basic meteorological studies relating the structure and dynamics of the atmosphere to the existing terrain. Some work in this vein has been done in the Valles Grande Caldera and preliminary plans were laid for further cooperative work between the laboratories and industry.

\section{Environmental Impacts}

The following review was written by Joe Shinn of LLL.

The objective of research on environmental impacts of pollution from hydrothermal development will be to develop and validate methods of forecasting potential air pollution effects. It is likely, based upon former studies, that no single pollutant will have significant ecological effect. on the other hand, the development of geothermal-hydrothermal resources at specific sites, such as the Baca location, will be 
constrained by public perception of uncertainties about damage from unidentified or unquantified pollutants.

A new tool, an air-pollution effects model, developed and utilized in previous geothermal and environmental studies, incorporates site-specific meteorological and dose-response data to forecast potential impacts and economic loss of vegetation. The model requires a team effort to obtain site-specific information and to be applied in an useful, validated manner. The following approach is suggested. Obtain meteorological and air-quality baseline data at the Baca or other hydrothermal sites with the inclusion of Imperial Valley Environmental Project instrumentation. Project ecosystem inventories (vegetation maps, soils maps, etc.) and identify the alternative development scenarios in a coordinated program with developers. Estimate air-pollution source-term data using existing techniques and participation in preliminary wellhead flow tests. Screen receptor organisms by simple controlled exposure studies to narrow the list of target species. Subject target plant species to short-term physiological dose-response and growth suppression studies for the important air-pollution emissions $\left(\mathrm{H}_{2} \mathrm{~S}, \mathrm{CO}_{2}, \mathrm{~B}\right.$, and perhaps others). Apply the existing air-pollution transport codes to estimate the geographical and temporal distributions of pollutants. Investigate the dominant tree and agricultural species sufficiently to permit calculation of potential economic loss for the alternative development scenarios.

The expected result of an effort like that described above will be a generic methodology that will have been applied and validated for a specific 
site such as the Baca location. It may aid in removing the barriers to the development of that site. The method should be applicable to other New Mexico sites and would add new air-pollution dose-response data which would be useful in other generic applications to the literature.

D. Human Health Impacts

The following review was written by Lynn Anspaugh of LLL.

Additional assessment work is needed in order to predict the impacts upon human health in quantitative terms. The needs are:

- Derivation of dose-response curves for the effects of hydrogen sulfide and other pollutants (benzene, $\mathrm{Hg}$, As). These are needed for other technologies, too, particularly where hydrogen sulfide may be a serious problem (oil shale and many other "synthetic" fuels).

- Refinement of existing occupational health statistics into rates.

- Analysis of the effects of cooling tower drift components ( $\mathrm{Hg}$, As, etc.) on humans through food-chain transport.

In order to support this assessment work and the calculation of human health impacts, additional measurements would be useful. These are: 
- Site-specific data on emission rates and calculated or measured concentrations of hydrogen sulfide, radon, mercury, benzene, and perhaps others not yet identified (arsine?).

- Site-specific data on deposition rates of chemicals in the cooling tower drift on vegetation.

Some simple epidemiological studies could also provide extremely useful data. There generally are sufficient acute exposure data for humans and animals, but we should search out suitable human populations that have had chronic exposure to low levels of geothermal pollutants and perform retrospective epidemiological studies. Large numbers of people have been exposed to low levels ( $\sim$ ppmv) of hydrogen sulfide in New Zealand.

Finally, it was recommended that we monitor human health directly in areas of significant geothermal development. This can be done easily (at least in some cases) by following mortality and morbidity statistics that are already available. Thus, while we commonly monitor air pollutants, usually to determine compliance with regulations, we may forget that regulations are generally established to protect human health. As it is probably much cheaper to monitor human health directly, this should be done. A compelling reason for doing so is that we may not be clever enough to always identify and measure the pollutants that represent the most significant hazards. 
At the end of the workshop, the participants were asked to write down their perception of the most pressing air-related problem that needed to be solved for the emerging hydrothermal industry. (Their responses are documented without identification in Appendix D.) Since the request was made without prior warning, the responses reflect "top-of-the-head" or "gut" opinions by those who have had experience in the field rather than cool, calculated evaluations. The following list is a condensation of the items which were mentioned. (See also the workshop follow-up letter in Appendix E.)

AIR TRANSPORT OF POLLUTANTS

- Fundamental studies of meteorology

- Measure and model the transport and diffusion of air-borne contaminants

- Develop a better understanding of flow pathways of $\mathrm{H}_{2} \mathrm{~S}$ at and near the Baca plant with regard to odor control

- Micrometeorology on public lands downcanyon from the Baca site

- Studies of vertical structuring of wind fields 


\title{
IMPACTS OF POLLUTANTS
}

\author{
- Interrelationships among source components, \\ transport and diffusion modes, and human \\ health and environmental impacts
- Assess the long-term effects of low concentrations of air pollutants on the environment and human health \\ - Assess the long-term ecological effects \\ - Impact of air pollutants on surface waters
- Develop methodology to forecast impacts of air pollutants

IDENTIFICATION OF POLLUTANTS

- Effluent stream sampling and source
characterization

The highest priority items identified were those dealing with air-transport predictions and actual pollutant impact, especially at low levels, on animals and plant life. Source sampling, although considered important, has already received significant attention, will continue to do so as the industry develops, and should be the responsibility of the companies. 
WORKSHOP ON ENVIRONMENTAL ISSUES

ASSOCIATED WITH WATER AND LAND

I. PRELUDE

Joe Shinn of LLL opened the informal workshop by impressing upon the four LASL and five LLL participants (see Appendix F) the need to develop a workplan on water and terrestrial issues. He stressed the need for participating organizations to work together and to emphasize the Baca and Imperial Valley developments and to deemphasize the Geysers efforts. Gene Wewerka of LASL reiterated the goal set forth earlier in the air-related issues workshop: i.e., to determine the research that is needed, not the problems that might exist.

II. CURRENT ACTIVITIES BRIEFING

Generally everyone present was well-versed in the background literature and work on water-related issues for geothermal energy. Bob Ireland of LLL, however, brought the group up-to-date on Livermore's recent findings. * Their research shows that ammonia, boron, potassium, and sulfate levels in some streams of the Geysers area are elevated. Finding the elements several miles from the plant sites would suggest that they are not completely localized as previously thought.

Three other pertinent programs are currently being conducted in the Geysers, in addition to the LLL program, which is providing information about aqueous transfer and accumulation of trace elements (e.g. As, B, and $\mathrm{Hg}$ ). U of California (Berkeley) is studying invertebrates, $U$ of California (Davis) is conducting a fisheries study, and PG\&E is doing a sedimentation and fish study.

\footnotetext{
* These results have been written up as UCID- 18605 .
} 


\section{ISSUE CONSIDERATIONS AND PRIORITIES}

Non-air-related concerns connected with hydrothermal technology include water quality, terrestrial impacts, noise, erosion and siltation, solid wastes, and seismicity. Several sources of solid wastes, such as drilling muds and cuttings, cooling tower sludges, and the Stretford process wastes, were identified. However, these are largely on-site problems that are not unique to the hydrothermal industry as other industries also have sludges and solids disposal problems. Adequate environmental control technologies now exist for such materials. Erosion and sedimentation are likewise common problems that many industries have and know how to handle. Noise is a potentially serious occupational problem that will have to be handled by the companies. Seismological implications and studies will require enormous expenditures and a great deal of time. The water/terrestrial impacts area appears to by far the most in need of attention.

Basically the water/terrestrial areas were handled in a similar manner as were the air-related issues. We considered the types of contaminants generated at the source, the manner in which these would be dispersed into the aqueous or terrestrial environments, and the types of impacts such dispersions would likely engender. Two sources of aqueous contaminants were identified as having high potential for environmental damage: 1) spills from raw or spent brines and 2) cooling tower drift.

Sources of brine spills would include the accidental discharge of raw brine from a well or piping prior to its entry into the power plant and the escape of spent brine prior to its reinjection. Potentially adverse damage to land or water from such spills could include thermal and salinity shock and residual chemical damage to the ecosystem. The major questions here are:

What types of detrimental environmental effects could be caused by brine spills? 
- What does it take to clean the spills up?

The potential implications of cooling tower drift deposition on the environment are just now beginning to be clarified. Prevailing opinion is that cooling tower drift is a highly localized phenomenon affecting perhaps a few hundred meters around the tower. The recent data from the LLL studies at the Geysers, however, suggest that some drift components are being dispersed to much greater distances. This could be due to secondary resuspension of the drift components or to a greater initial air-borne dispersion than originally thought. The potential chronic effects caused by the long-term dispersion of contaminants contained in cooling tower drift are an obvious concern to those outside the plant boundary.

Another type of water impact was also considered important. This is the long-term effects of continuous hydrothermal activity on the quality and quantity of the regional water resources. For the Jemez River watershed, more information is needed to identify surface recharge mechanisms, the potential impacts of brine reinjection, aquifer drawdown, and aquifer contamination. 
RESEARCH PRIORITIES AND RECOMMENDATIONS

This section presents a brief summary of the workshops and identifies the technical tasks that have been proposed for DOE to pursue. It also includes an assignment of these tasks to the organizations that are best suited to accomplishing them.

The mid-April workshop at LLL and the Geysers covered many non-air-related environmental concerns connected with hydrothermal development. These included water quality, terrestrial impacts, noise, erosion and siltation, solid wastes, and seismicity. Several sources of solid wastes in the hydrothermal technology, such as drilling muds and cuttings, cooling tower sludge, and stretford process wastes, were identified. These are largely on-site problems, however, that are. not unique to the hydrothermal industry. Erosion and sedimentation are, likewise, common industrial problems that are widely addressed. Noise is a potentially serious occupational problem that will have to be handled by the Companies. Seismological implications and studies will require large resources and a great deal of time and should be included in an expanded monitoring program. Considering the above, the workshop singled out the water quality/terrestrial impacts area as needing immediate research attention. Two sources of aqueous contaminants were identified as having high potential for environmental damage: well and pipe blowouts and cooling tower drift.

Sources of brine spills would include the accidental discharge of raw brine from wells or piping prior to its entering the power plant and the loss of spent brine prior to reinjection. Potential adverse damage to land or water from such spills could include thermal shock, salinity shock, and residual chemical damage to the ecosystem. The major questions to be answered are: what types of detrimental environmental effects could be caused by brine spills? how persistent are the effects of such spills? and what does it take to clean them up? Prevailing opinion is that cooling tower drift is a highly localized phenomenon affecting perhaps a few hundred meters around the tower. Potential widespread, but low level, deposition into the environment has been signalled by LLL, however. Their studies at the Geysers suggest that such drift components as boron and sulfate are being dispersed to greater distances in the environment than previously 
thought possible. The potential chronic effects caused by the long-term dispersion of contaminants contained in cooling tower drift are of obvious concern.

A third type of water quality impact was also thought to need attention. This concerns the long-term effects of continuous hydrothermal activity on the quality and quantity of the regional water resource. For the Jemez River watershed, more information is needed to identify surface water recharge mechanisms, the potential impact of brine injection, aquifer drawdown, and aquifer contamination.

The mid-March workshop at LASL covered issues surrounding the potential air-quality impacts from hydrothermal development. Four main areas with regard to air quality were discussed: source sampling and analysis, contaminant transport and dispersion, environmental effects, and human health effects.

In the source sampling and analysis area, the workshop participants generally agreed that a great deal needs to be learned about how to properly sample the various geothermal effluents and how to analyze the effluent constituents accurately and repetitiously. Our retrospective judgment on this issue, however, is that it should be handled by the Companies and their contractors who are monitoring on-site. Of course, DOE laboratories would be available for consultation and to provide help if requested.

The ability to measure and predict the way that air-borne constituents $\left(\mathrm{H}_{2} \mathrm{~S}\right.$, boron, etc.) transport and diffuse from their source at a hydrothermal site was deemed important in predicting the potential impacts of future developments. The workshop participants generally agreed that learning how to measure and model contaminant dispersion, especially in complex terrains, should be be a major component in a DOE research program.

The major item of concern in the area of human and environmental effects was hydrogen sulfide. In discussing this issue during and after the workshop, we concluded that the hydrothermal industry is likely to be constrained by emission standards at the nuisance leve1 ( 5 to $10 \mathrm{ppb}$ ) and that at these levels acute health and environmental effects are not likely to be a problem. The possibility of chronic effects from $\mathrm{H}_{2} \mathrm{~S}$ are a different matter. There is little experimental 
work that seems justifiable, however. The workshop members generally agreed that an epidemiologic study of a human population that resides in an area, such as some found in New Zealand, with elevated $\mathrm{H}_{2} \mathrm{~S}$ levels could provide information about chronic effects of nuisance levels of $\mathrm{H}_{2} \mathrm{~S}$ •

of the other possible air-borne contaminants that could be emitted from the hydrothermal industry, boron was singled out as a potential cooling tower problem at some plants. (Distant terrestrial impact from cooling tower drift was considered as a water/land issue and treated as such.) We felt that the initial studies of the cooling tower drift itself should fall under the purview of the Companies and their on-site monitors. DOE laboratories would provide technical support at a latter date if requested.

As a result of our workshops and subsequent discussions, we have Identified three technical tasks dealing with the impacts of hydrothermal activity on aqueous and terrestrial ecosystems which DOE should address soon:

1. Assess the potential impacts of geothermal brine spills on terrestrial and aquatic ecosystems;

2. Assess the effects of deposition and resuspension of cooling tower drift components on terrestrial and aqueous ecosystems; and

3. Evaluate the potential impacts of hydrothermal energy extraction on regional water resources.

In addition, we have identified two technical tasks in the air quality area for DOE attention:

4. Develop a capability to measure and predict how $\mathrm{H}_{2} \mathrm{~S}$ and other air-borne contaminants disperse in complex terrains; and

5. Determine the chronic impacts of low levels of $\mathrm{H}_{2} \mathrm{~S}$ on human health.

Three non-air/non-water-related technical tasks have also been identified: 
6. Determine influences on wildlife habitat and health. This would primarily deal with the on-site elk herd, but would extend to aquatic animals too;

7. Evaluate the seismic impact of hydrothermal source removal and reinjertion. This would be a logical extention of the preisent LASL, hot dry rock, seismic network $10 \mathrm{~km}$ away; and

8. Characterize the soucce terms at the production site. This would be done a:s requested by the industrial operators or if the need arose.

The following tabulation identifies the organizations most suited to carry out each task for the DOE/ASEV hydrothermal project connected with the Baca location:

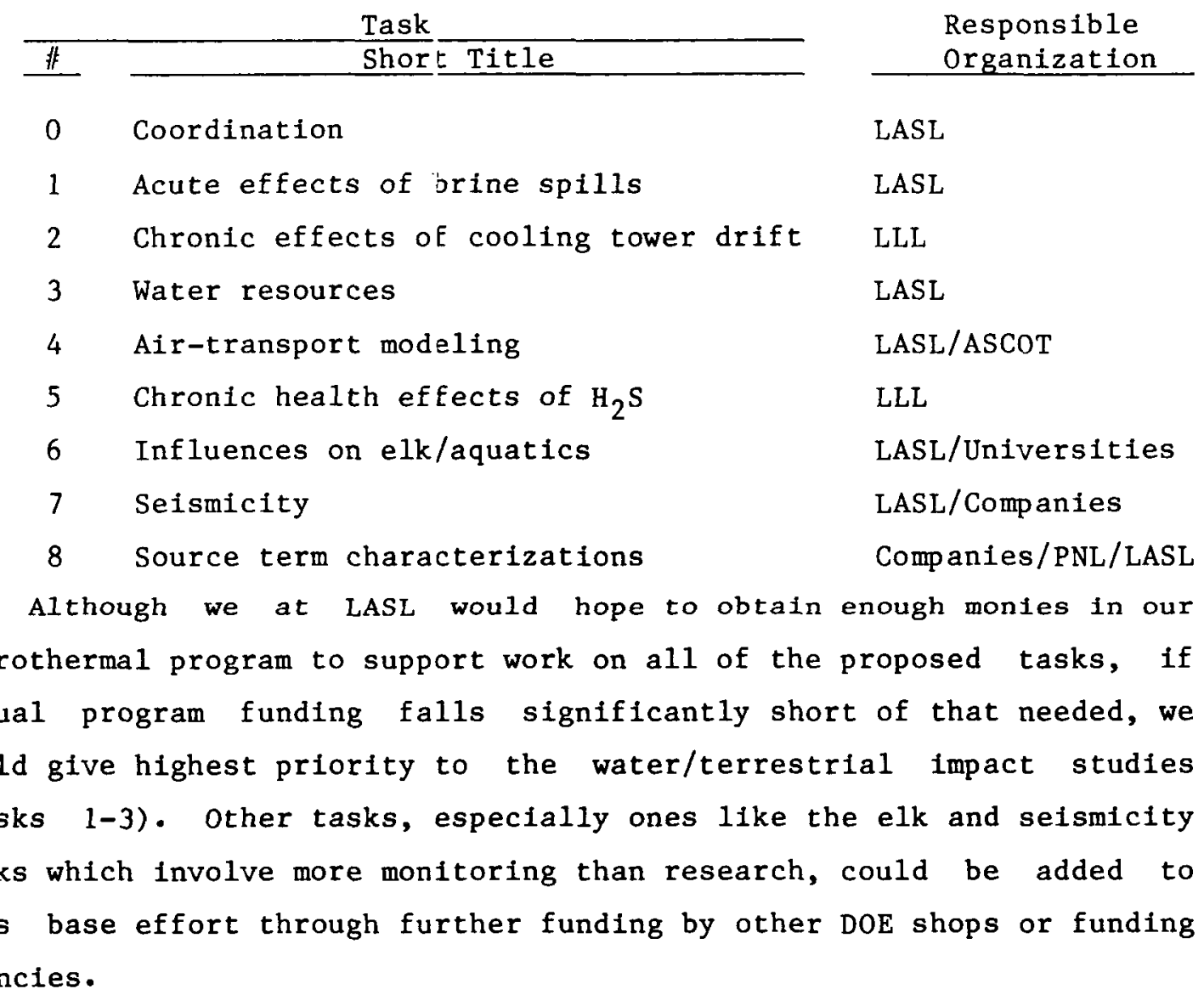




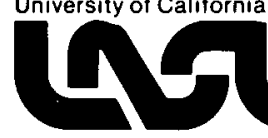

Post Office Box 1663 Los Alamos, New Mexico 87545

Mr. Gary Langhorst

Los Alamos Scientific Laboratory

P.0. Box 1663

MS -495

Los Alamos, NM 87545

Dear Gary:

Thanks for agreeing to take part in an informal workshop at LASL on March 11 and 12, 1980, to discuss the potential health and environmental impacts of air-borne contaminants produced by the liquid-dominated geothermal resource, and to help structure a research plan to assess the nature and magnitude of such impacts. The possible air quality impact engendered by the hydrothermal resource is but one of several health and environmental issues that are included in the LASL program "Environmental Readiness Assessment of the Generation of Electricity from Liquid-Dominated Geothermal Resources." A brief description of this program is enclosed.

As I mentioned in our earlier conversations, the workshop is intended to be an informal meeting where we can maximize communication and information exchange. The first morning of the workshop (see enclosed) will be devoted to a series of overview presentations concerning the interests and capabilities of some of the participants, the technology for extracting the hydrothermal resource, and the meteorological and environmental setting of the Baca demonstration plant. Discussions of the potentially adverse impacts of alr pollutants generated by the hydrothermal technology, and the development of a technical plan to assess these impacts, will occupy the afternoon of the first day and the next morning.

For the purpose of discussion, I have subdivided the question of air quality impacts into flve separate technical issues: source characterization, pollutant transport and dispersion, environmental impacts, human health impacts, and predictive modeling of pollutant transport, dispersion and impacts. Undoubtedly there are some overlaps and holes in this breakdown, but these are at least areas on which to begin to focus.

As you will note from the agenda, I have asked several people to be discussion leaders for the Tuesday afternoon and Wednesday morning sessions. Each discussion leader will begin with a few comments concerning their own conceptions of what we need to cover for each 1ssue. Also, subsequent to the workshop, the discussion leaders will summarize the results of the sessions, and will send them to each of the participants. I am hopeful that we can formulate the major aspects of our research plan during the workshop, but, if not, we can use the input of the discussion leaders as the means for doing so. 
The workshop will end before noon of the second day. However, for those who desire, we hive arranged to drive to the Valles Caldera in the early afternoon to observe the area. It does not appear $11 k e l y$ that we will be able to visit the Baca hydrothermal development site at this time.

$$
\text { All of the workshcp meetings will be held in the conference room of }
$$
the Occupational Healtt. Office Bullding at LASL. Out-of-town participants will lodge at the Los tlamos Inn during thefr stay. Local transportation will be provided.

Again, I would like to thank you for your help and participation; I look forward to an interesting and productive workshop. Please call if questions arise.

Sincerely yours,

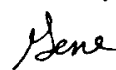

Eugene M. Wewerka

LS-6 Group Leader

Environmental Science

EMW : em

Enc: a/s 
WORKSHOP ON AIR QUALITY ISSUES ATIENDANT

TO HYDROTHERMAL RESOURCE DEVELOPMENT

Los Alamos Scientific Laboratory

Conference Room

Occupational Health office Buflding

\section{Agenda}

Tuesday, March 11, 1980

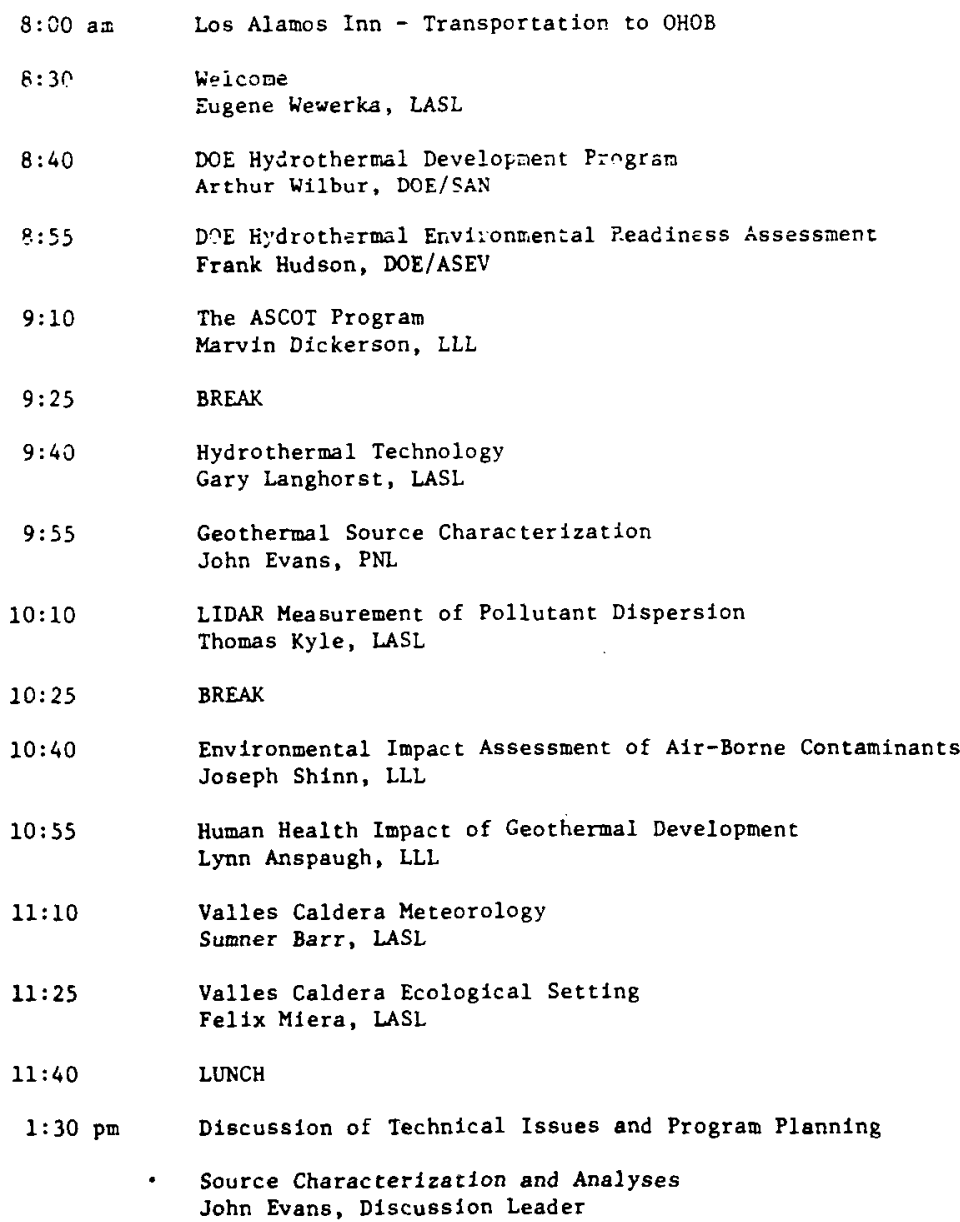




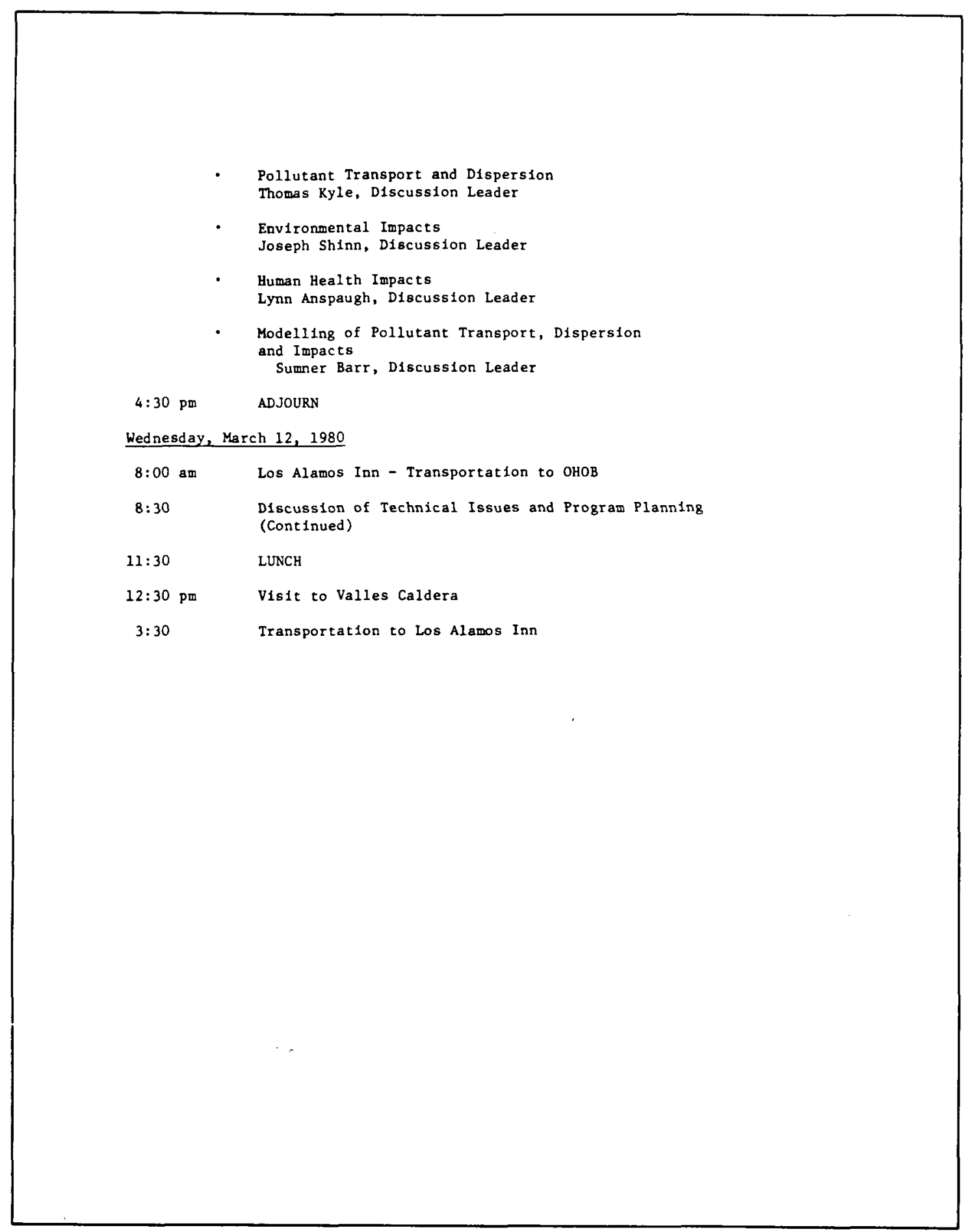




\section{APPENDIX B}

ATTENDEES TO LASL HYDROTHERMAL AIR-BORNE CONTAMINANTS WORKSHOP

Lynn R. Anspaugh

LLL, P. O. Box 5507, L-453

Livermore, CA 94550

FTS 532-3880; (415) 422-3880

Sumner Barr

G-8, MS-588

Los Alamos Scientific Laboratory

Los Alamos, NM 87545

FTS 843-2701; (505) 667-2701

Lyle Rae Burger

Union Geothermal of NM

4100 Southern Blvd.

P. 0. Box 15225

Rio Rancho, NM 87174

(505) 897-1776

Harry Ettinger

$\mathrm{H}-5$, MS -486

Los Alamos Scientific Laboratory

Los Alamos, NM 87545

FTS 843-5231; (505) 667-5231

John C. Evans

Battelle Northwest Laboratory

329 Building/300 Area

P. 0. Box 999

Richland, WA 99352

Roger W. Ferenbaugh

$\mathrm{H}-8$, MS -490

Los Alamos Scientific Laboratory

Los Alamos, NM 87545

FTS 843-7952; (505) 667-7952

Thomas E, Hakonson

LS-6, MS-495

Los Alamos Scientific Laboratory

Los Alamos, NM 87545

FTS 843-2426; (505) 667-2426
Frank P. Hudson, Ev-34

Department of Energy

Washington, DC 20545

FTS 233-4066; (301) 353-4066

John Koranda

LLL, Box 5507, L-453

Livermore, CA 94550

FTS 532-0909; (415) 422-0909

Thomas G. Kyle

$\mathrm{H}-5$, MS -494

Los Alamos Scientific Laboratory

Los Alamos, NM 87545

Ken Lamson

LLL, P. 0. Box 5507, L-524

Livermore, CA 94550

FTS 532-6845; (415) 422-6845

Gary Langhorst

LS-6, MS-495

Los Alamos Scientific Laboratory

Los Alamos, NM 87545

FTS 843-3300; (505) 667-3300

Caroline Mect

LS-6, MS-495

Los Alamos Scientific Laboratory

Los Alamos, NM 87545

FTS 843-3132; (505) 667-3132

Felix R. Miera, Jr.

LS-6, MS-495

Los Alamos Scientific Laboratory

Los Alamos, NM 87545 


\section{APPENDIX B (contd)}

Chuck Molenkamp, L-292

Lawrence Livermore Laboratory

P. 0. Box 808

Livermore, CA 94550

FTS 532-1827; (415) 422-1827

Consuelo Montoya

LS-6, MS-495

Los Alamos Scientific Laboratory

Los Alamos, NM 87545

FTS 843-5577; (505) 667-5577

Joel Robinson

P. 0. Box 7600

Union 0il Center

Los Angeles, CA 90051

(213) 486-7398

Dave Sabo

PNM-Env. Affairs

P. 0. Box 2267

Albuquerque, NM 87103

(505) 842-8905

Tracy Schofield

LS -6 , MS-495

P. 0. Box 1663

Los Alamos Scientific Laboratory

FTS 843-3301 (595) 667-3301

Joseph H. Shinn

Lawrence Livermore Lab

Environmental Sciences Division

P. O. Box 5507 L-524

Livermore, CA 94550

FTS 532-6806; (415) 422-6806

E1iza Trujillo

LS-6, MS-495

Los Alamos Scientific Laboratory

Los Alamos, NM 87545

FTS 843-5577; (505) 667-5577
Lawrence Wangen

LS-6, MS -495

Los Alamos Scientific Laboratory

Los Alamos, NM 87545

FTS 843-4896; (505) 667-4896

Eugene M. Wewerka

Environmental Science Group, MS-495

Los Alamos Scientific Laboratory

Los Alamos, NM 87545

FTS 843-3331; (505) 667-3331

Gary C. White

LS-6, MS-495

Los Alamos Scientific Laboratory

Los Alamos, NM 87545

FTS 843-2914; (505) 667-2914

Arthur C. Wilbur

DOE, Rm. 712

600 2nd St. NW

Albuquerque, NM 87123

FTS 474-3822; (505) 766--3822

Joel M. Williams

LS-6, MS-495

Los Alamos Scientific Laboratory

Los Alamos, NM 87545

FTS 843-7887 (505) 667-7887

Ralph Williams

PNM/Air-Water Quality

P. 0. Box 2267

Albuquerque, NM 87103

(505) 842-9263 


\section{APPENDIX C}

DISCUSSIONS IN THE AIR-BORNE CONTAMINANTS WORKGROUPS

for

Workshop on Environmental Issues Associated with Air-borne Contaminants held in Los Alamos, NM from March 11-12, 1980 .

These discussions were taken from the notes of Joel M. Williams and have been ordered slightly to keep single topics together. The commentor is identified where possible.

\section{SOURCE CHARACTERIZATION AND ANALYSES GROUP}

John Evans briefly reviewed the pollutants being emitted and pointed out that, since cooling towers are difficult to sample because of the non-uniform region above the fans, it is difficult to know what is being emitted. He also brought up the issue of benzene and other organics in the effluent steam.

Gene Wewerka suggested that the health effects of only those organics above background levels should be determined. He also wondered about the boron problem and its movement by flash flood storms. Joel Robinson asked about the brown sludge around the towers. Lynn Anspaugh identified it as cooling tower catalyst.

Ralph Williams said he knew of no work to sample cooling towers. Joel Robinson suggested that a mass balance might be better than trying to get a representative sample over the cooling towers. He expanded by stating that the problem is complicated by the two-phase (steam/water) nature of the streams. The ratio of these two phases will have to be determined anyway to evaluate water rights. Joel Williams suggested that the air pollution problems should be related to measurable process variables. This could be done statistically.

Gene Wewerka asked about techniques to measure the levels of $\mathrm{H}_{2} \mathrm{~S}$. Ralph Williams said that $10 \mathrm{ppb}$ is the confident detection level for $\mathrm{H}_{2} \mathrm{~S}$. The ensuing discussion illuminated that LLL has a mobile monitor and that the best $\mathrm{H}_{2} \mathrm{~S}$-detection method can detect $\sim 1$ pp : flame photometry ( $1 \mathrm{ppb})$, lead acetate ( $5 \mathrm{ppb})$, and oxidation to $\mathrm{SO}_{2}$ (3-4 ppb). Ralph Williams mentioned that the burden for proof of compliance is on the operator. He stated that $\mathrm{SO}_{2}$ and particulate emissions must also be addressed, but they will not be a problem at the levels emitted. 
POLLUTANT TRANSPORT, DISPERSION,

Tom Kyle opened the discussion by likening the Baca area to a big bowl which continues to fill without an inversion. He thought that a maximum amount of pollutant at anytime was unrealistic and suggested that a maximum level for a percentage of time would be better, especially for an oxidatively unstable pollutant like $\mathrm{H}_{2} \mathrm{~S}$ in an area with as much sunshine as New Mexico has.

Joel Robinson stated that no federal standard exist for $\mathrm{H}_{2} \mathrm{~S}$ in the atmosphere. He would like to see the $\mathrm{H}_{2} \mathrm{~S}-\mathrm{release}$ values tied to the meteorology. Currently the procedure is to "shovel in" iron oxide when the meteorology is "bad" and stop when it becomes "good". He asked what input ASCOT could give. He would like to see the least amount of monitoring to get the maximum results. Sumner Barr said that ASCOT is trying to narrow the limits on the variables needed. The eventual model will not be all-encompassing. Approximately six models are currently being worked on. Joel Williams asked what parameters are needed for the models.

Tom Kyle asked about the significance of the meteorology and transport within a few meters of the ground. Frank Hudson said that topography is quite important and that the pollutant movement is a micrometeorological problem rather than a macrometeorological one. Joel Williams asked whether flow around trees is different than in the atmosphere. Sumner Barr said that plants can cause drag and that the models might be able to be modified for gross drag. Gene Wewerka and Dave Sabo both recalled having seen reports of some work (Savannah River?) on micrometeorology. Gene Wewerka questioned where the pollutants might be concentrated: 0-2 meters, 6-20 meters, etc. Joel Robinson stated that plume above the cooling tower can rise 100-300 meters. Tom Kyle stated that LIDAR can be used to determine the 3-dimensional nature of plumes and that, by using different wavelength dyes, several intermixing plumes can be followed.

\section{ENVIRONMENTAL IMPACTS GROUP}

Joe Shinn presented an itemized review of the issues that he perceived to be significant. These included inputs, such as knowledge of the pollutant sources and the development scenarios to be used. An inventory of the plant population is needed and the vegetation needs to be mapped, especially as primary and secondary receptors. Soils need to be typed. Plant species, especially economically useful ones, need to be ranked with respect to their sensitivities to pollutant-induced phenomena, such as defoliation and photosynthesis reduction. Air monitoring and transport data need to be used to evaluate levels of pollutants. LLL used four -4 week periods in some of their evaluations in the Imperial Valley.

Joel Williams suggested that changing the environment from one acceptable form to another equally acceptable form might be a reasonable course of action. Frank Hudson mentioned that some species can tolerate $\mathrm{H}_{2} \mathrm{~S}$ and other pollutants. 
HUMAN HEALTH IMPACTS GROUP

Lynn Anspaugh illustrated the need for dose-response curves for $\mathrm{H}_{2} \mathrm{~S}$ and other pollutants with curves. Some "pollutants" have a minimum requirement for good health too. He stated that occupational statistics need to be refined into rates. He felt (and most everyone else did too) that enough acute studies had been done. Chronic (long-term) exposure effects are needed, however. He felt that human responses should be measured directly.

Joel Williams asked about using EPA's MEG/MATE evaluation system for pollutants and whether any EPA Level I bioassay tests had been run. Lynn Anspaugh said that he thought we could do better than the MEG/MATE evaluation with only a limited number of pollutants in the hydrothermal project. Frank Hudson said that no hydrothermal brines had been subjected to toxicity tests, such as the AMES test, but that others are studying these problems and that the brines should be run when they become available. 


\section{$\underline{\text { APPENDIX D }}$}

INDIVIDUAL RESPONSES TO THE QUESTION OF THE MOST PRESSING, AIR-RELATED ISSUE FOR HYDROTHERMAL DEVELOPMENT

These responses were solicited without prior warning at the end of the Workshop on Environmental Issues Associated with Air-borne Contaminants held at Los Alamos, NM from March 11-12, 1980. They are listed in no special order and are presented anonymously.

\section{RESPONDER 1:}

There is no single and simple issue that I can state that alone will enhance the development of geothermal energy from a health and environmental viewpoint. Issues and effects are interrelated and need to be considered together and in tandem. In my view the critical areas in need of enlightenment are:

1. Standardized and reliable techniques for collecting effluent samples at the generation site and at the points extant from such sites.

2. Standardized and reliable techniques for monitoring and following pollutant transport and dispersion into the environment.

3. A much better understanding of threshhold limits and levels of safety regarding the impacts of geothermal effluents on the environment (plants, animals, soils) and human health needs to be developed.

4. Integrated models incorporating the understanding and knowledge from $1-3$ above need to be established to allow companies, regulation agencies, etc. to apply the information to various development scenarios to evaluate the impacts of geothermal development vis a vis other social, economic, and energy-development possibilities.

Only in this way is there a chance that sufficient and convincing information will be available to avert the long and costly delays that will accompany every increment of expansion that the Baca people and others will experience due to public resistance and misinformation.

\section{RESPONDER 2:}

In an area of limited water resources the impact of geothermal power must be minimal upon that resource. This will be important for 
social acceptance of the alternate energy program. The Baca project is going to be an excellent opportunity to resolve this issue. A program that coordinates between participants and research personnel will be a major step towards this goal. If a "path" of cooperation can be set whereby industry, utilities, and government can work together constructively, I believe many problems can be overcome (e.g. water resource, Baca).

Three major points which could be used, specifically for the Baca project, might be:

\section{Predictive modeling capability \\ 2. Transport of pollutants through the biospheres studies}

3. A common data base system

\section{RESPONDER 3:}

There appear to be two things that can inhibit the development of hydrothermal resources at the Baca. One is the uncertainty about impacts upon the environment and human health, and the other is socioeconomic and relates to concerns of the Indians.

These should be approached by the following:

1. Preparation of a detailed predictive assessment of environmental and human health inpacts. This would include:

a. Scenario of energy development (MW vs time)

b. Source-term measurement $(g / M W e \cdot h)$

c. Calculations of airborne concentrations

d. Calculations of environmental and health impacts. (May need supporting basic research, such as threshhold injury functions for vegetation and human epidemiology studies.) Needs to include effects of cooling-tower drift and food-chain transport.

2. Preparation of a detailed predictive assessment of socioeconomic effects, including a method of dealing with the real concerns of the Indians.

Suggestion 1 should proceed immediately (everyone will say they can't do it until $x$ years of research, but it should be forced to 
discover what the holes really are). It seems naturally to be a joint effort of LASL, LLL, PNL, Union and PNM.

Sugestion 2 should be done by a local person who understands the peculiarities of the region.

\section{RESPONDER 4:}

The developers and utilities will be performing met (meteorological) monitoring on the Baca Ranch, yet there are down-canyon effects that are only generally understood. In addition, USFS leases down-canyon have had no met monitoring to date and yet may contribute a substantial amount to nearby public areas.

A complementary met program could be developed to ascertain "micro" meteorology on public lands. Certainly meteorologist and modelers from LASL would be the most likely candidates to perform this work. Sumner Barr could organize the effort.

This work would be of direct and immediate benefit for the siting and permitting of new plants on the private property, and could benefit the entire Jemez area as development expands out to public lands.

\section{RESPONDER 5:}

We need to:

1. Address characterization of the source. This would require studying the engineering and usage of the cooling towers so that the measurements of the source may be reliably taken.

2. Define the effects of $\mathrm{H}_{2} \mathrm{~S}$ - if any - on humans. Lynn Anspaugh could summarize existing knowledge (what levels, etc.)

3. Develop a knowledge of the complex terrain modeling so that reliable predictions can be made on any mountainous region. This would, no doubt, require a more regional study of meteorology than PNM/Union are dolng.

4. Define the sensitive (to geothermal pollutants) vegetation types in any area. The Jemez is no exception. 


\section{RESPONDER 6 :}

The major issue is the odor nuisance of $\mathrm{H}_{2} \mathrm{~S}$. I see two major problems that could be addressed at Baca:

1. Interaction of synoptic flows and local flows. Drainage of the caldera under influence of synoptic overflow is a logical extension of ASCOT techniques from nocturnal drainage to boundary layer-synoptic interaction. Major emphasis would be on meteorological data and tracer experiments over the caldera, for comparason with ASCOT-developed modeling techniques.

2. Transformation of 2-phase geothermal fluid as it passes through separators, turbines, condensers, and cooling towers is poorly understood. This first full-scale flash-steam power plant should be used for research on these processes, particularly in determining what happens to $\mathrm{H}_{2} \mathrm{~S}$ as it transits the plant and exits the cooling tower. Estimates of emissions for future plants, based on such new information, would be much more reliable. Emphasis in such a study would be cooling tower emissions measurements.

\section{RESPONDER 7:}

The problem I suggest is a determination of the fate of the different materials released by the geothermal plant. This would look at, for example, where the boron released eventually comes to rest. the work would have some maximum range such that a certain fraction would be considered to be transported out of the area. In the case of $\mathrm{H}_{2} \mathrm{~S}$, it would determine not only the average path to the eventual deposition, but something as to if this is primarily a nighttime or daytime process or if it occurs primarily during one season.

The work would involve, first, tracer studies to indicate the transport paths; secondly, receptors to provide information on the concentrations of the materials; and, thirdly, analyses of solls, plants, and animals for the concentrations of the materials. Very little work would be done on the materials after they have come to rest on a stationary surface, such as a plant leaf. The effects on the plants and the soils can best be studied at specialized sites, not in the field.

Models of the mode of transfer would be developed, not of the flow direction, but of the mechanism, such as is the material captured on some particular aerosol for the transport or does the chemical form change during the transport. This would allow the sensitive conditions of the transport process to be identified. 
The rationale of this type experiment is that the air quality standards specify what quantity of material can be in the air. The remaining important question is where do the materials go. If we know where they go, it is straightforward to determine what the effects might be with complex field programs.

RESPONDER 8:

Problem A: Characterize the long-term impact of low concentrations of air pollutants on a complex multitiered vegetation. Research is continuing at many areas in the USA. Dave Sabo would be a good contact person. A general review of the literature would be useful.

Problem B: Characterize long-term impacts of low concentrations (less than lethal or less than what would produce acute symptoms of poisoning) of $\mathrm{H}_{2} \mathrm{~S}$ on people. A review of health documents from "study" areas within concentrations of $\mathrm{H}_{2} \mathrm{~S}$ and comparison with a nearby population for chronic complaints of sinusitis, headaches, respiratory distresses, eye problems - 1000 or 100000 individuals. Lynn Anspaugh would be a person qualified to work on such a study. Populations in New Zealand are "readily" available. Joel Robinson could possibly provide information.

\section{RESPONDER 9:}

The most important impediment to geothermal development is the public perception of air pollution impact. The problem must be addressed at each development site. The approach we should take is to develop our recently proven methodology to forecast air pollution effects, together with whatever experimental data is required to validate our method for the Baca site and/or other sites.

A team effort should be utilized to obtain scenarios of geothermal development, quantify the emission source terms, inventory plant and animal receptor populations, obtain time series data by air monitoring, obtain available transport codes, screen receptor organisms for sensitivity, obtain physicological dose-response for target species, and calculate potential impact and economic loss.

We at LLL would be pleased to provide the effects-computational models, and to determine the dose-response of target species so that the forecast can be made. LASL should provide the remainder of the above with the exception of quantifying the source term which should be done by PNL.

\section{RESPONDER 10:}

The Valle Grande Caldera site presents several characteristics that are unique to the geothermal development sites. It has a discrete, uncomplicated geochemical environment more so than the Geysers area, and certainly different from the agricultural scene in the Imperial Valley. 
The major goal that could be achieved in the Valle Grande Caldera area is an assessment of the long-term ecological effects of geothermal plant operation. The acute effects of that expected for some close-in problems. The major generic contribution to the description of geothermal energy development effects will therefore be the long-term ecological cost or impact of the energy source. In other words, do contigious ecosystems gradually become "poisoned" by the presence of a geothermal plant, or can those ecosystems buffer and absorb the relatively low influx of chemicals from the power plant complex.

There is preliminary evidence that short-term effects are not large and generally acceptable except where odor problems occur in urban areas.

The Geysers site is not appropriate for long-term studies of the type suggested here, primarily because of its complex history, geochemistry, and widespread development. The Imperial Valley, our next geothermal site to come on-line, has such a unique set of endemic factors operating in its agricultural ecosystem that general concepts are difficult to extrapolate to other areas.

In summary, the Baca site is our best available geothermal area in which to assess acute air-pollution effects, intermediate to long-term ecological and surface hydrological effects on the ecosystems of the area. The methods for assessing these three effects areas are presently within our expertise and require no extensive development.

RESPONDER 11:

The vertical wind field is very difficult to determine yet is an extremely important part of Baca field mixing, drainage, etc., involved in $\mathrm{H}_{2} \mathrm{~S}$ diffusion, etc., resulting in final $\mathrm{H}_{2} \mathrm{~S}$ concentrations. Conventional ground based meteorological systems give little or no vertical information, so a doppler acoustic system would be most useful on limited use basis to obtain this important information needed to predict $\mathrm{H}_{2} \mathrm{~S}$ environmental levels.

This study should be under the supervision of NOAA, Boulder (Bill Neff), but could be run out of the local area, probably by LASL, or by Union with subcontract with Aeroenvironment, etc.

\section{RESPONDER 12:}

The Baca location should be regarded as a model case for source characterization. This means careful source characterization of all possible species at every point of development. Among other thing, this will allow us to assess the validity of flow test data against that obtained from an actual plant. Finally an intensive effort should be made to obtain accurate cooling tower data. $\mathrm{H}_{2} \mathrm{~S}$ and airflow should be carefully mapped over a very large number of points on each cell. This type of program does not involve a really massive effort, but does go beyond previous efforts and should help provide better guidelines for sampling other situations. A careful effort should also be made to 
assess the uncertainty in this source term. In particular, temporal variability must be assessed by repeating the exercise several times.

RESPONDER 13:

The meteorology of the Baca geothermal site is unique in terms of the local topography, the altitude, and the larger scale meteorological setting and, therefore, needs to be studied in order to address important site specific transport, deposition, and environmental effects problems. However, the fundamental knowledge that would evolve from local studies will fill critical needs in broader contexts of terrain-influenced meteorological structure and, therfore, will extend to other energy development locations. The meteorological studies (field measurements, monitoring, data interpretation, and theory) that are performed for the Baca site should be fundamentally based and include enough measurements that the interpretation can be extendable through related programs (e.g. ASCOT) to other sites.

The general meteorology and site topography are ideal for studies of locally dominated, boundary-layer flow regimes in seasons of weak synoptic scale influence. In seasons of vigorous large-scale winds the interaction of local and outer flow domains can be well studied. The existence of industrial development at such a high altitude is a unique opportunity to investigate the effects of solar and long-wave terrestrial radiation.

The program will run in parallel with ASCOT, but have a different objective - the practical assessment of concepts and techniques being developed in ASCOT. A liaison must be maintained between the two research programs to feed vital information both ways.

Research plans can be productively laid through an interlaboratory group with objectives of meteorology and practical assessment. A strawman group might include:

Sumner Barr, LASL

Ralph Williams, PNM

Joel Robinson, Union

Meteorologist/field experimenter, LLL, PNL

RESPONDER 14:

Al1 environmental and health effects studies or assessments are highly dependent on the source term. In fact, such studies may not be necessary if a "worst case" analysis shows no possible effect. Therefore it seems imperative that a fairly good quantification of emissions rates be obtained and that potentially troublesome species not be missed because of unsound guesses as to which contaminants should be measured. Hence, I would urge that methods be developed for sampling of the various effluent streams that are satisfactory for answering the source-term question, and that these samples be analysed in sufficient detail for making scientifically sound statements 
regarding the possible extent (or lack thereof) of any effects due to a given potential contaminant.

Groups with experience in sampling include PNL and the industry. The industry, in particular, will find it necessary to sample their effluent streams. Perhaps a small working committee consisting of appropriate individuals should address the problem of sample acquisition. The other issue of sample characterization requires gaseous, liquid (also solids?) analysis of both organic and inorganic constituents. LASL has extensive capabilities in both of these areas as do several other DOE laboratories.

RESPONDER 15:

Any impact to water resources in this region is of importance in that this resource is limited and depended upon for agricultural, recreational and domestic needs. An area not covered at this workshop, due to limited time, is the potential for impact to surface waters by atmospheric pollutants. I feel that in fresh water systems, we need to first examine what may be available from the literature. Potential areas of concern include direct deposition, either airborne or precipitation washout, which is probably not a significant problem, and indirect introduction of contaminants by runoff. Questions that need answering include transfer to abiotic and biotic components, effects and fate of contaminants, and most importantly persistence of effects. Studies are necessary at both the laboratory level and those related to field conditions. At LASL, our programming plans are being developed along these lines, not only concerning air quality, but other issues a1so.

RESPONDER 16:

Level I Chemical and Biological assessments of the full spectrum of pollutants need to be performed to evaluate completely the acute toxicity of gas, liquid, and solid discharges. Chronic effects appear to be a major question in peoples ' minds and will always remain until someone addresses them. The main problem here is how to measure these long-term low-level effects, especially in a short period of time.

Sensitivity factors are needed to quantify causes and effects. This can result only by combining the major components - source (production), transport (meteorology), levels (monitoring), and impacts (assessment) - in a manner which will permit their interrelationships to be evaluated. This would be an extension of the upstream/downstream feedback systems now used in chemical process control. It is the common goal to which the various groups should focus to integrate best their work into a unified picture. This approach also delineates clear boundaries of responsibilities.

In the area of ecological impacts, I believe that levels and transport through soils and in water are important. We need to know the types and extent of influence that the pollutants will have. Do low level pollutants act synergistically? 


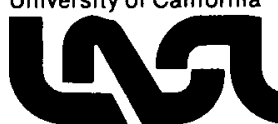

\section{LOS ALAMOS SCIENTIFIC LABORATORY}

Post Office Box 1663 Los Alamos, New Mexico 87545

Mr. Joel Williams

CMB-8, MS-734

P. O. Box 1663

Los Alamos Scientific Laboratory

Los Alamos, NM 87545

Dear Joe1:

I want to thank you again for helping to make the hydrothermal air quality workshop a success. We covered'a lot of ground in the two days that we were together, but $I$ an confident that the effort was well spent.

I will send you the summary narratives for each of the technical sessions as soon as I receive them from the discussion leaders. Also, based on the workshop, we will attempt to structure a technical program to address the air quality issues within the context of our generic assessment program. I will be back in touch with you to get your comments about this latter item.

You may be interested in the outcome of our survey concerning individual perceptions of the single-most pressing (air quality?) problem to be solved for an emerging hydrothermal technology, with specific reference to the Baca demonstration plant. The responses were indeed varied:

- Impact of air pollutants on surface waters.

- Effluent stream sampling and source characterization (2).

-Fundimental studies of meteorology.

- Interrelationships among source components, transport and diffusion modes, and human health and environmental impacts (4).

-Studies of vertical structuring of wind fields.

-Assessment of long-term ecological effects.

- Develop methodology to forecast impacts of air pollutants.

-Assess the long-term effects of low concentrations of air pollutants on the ervironment and human health.

-Measurement and modelling of the transport and diffusion of air-borne contaminants. 
LOS ALAMOS SCIENTIFIC LABORATORY UNIVESTY OFW CALIFOBNIA

TO:Mr. Joel Williams LS6-80-101

$-2$

DATE: March 20, 1980

- Develop a better understanding of flow pathways of $\mathrm{H}_{2} \mathrm{~S}$ at and near the Baca plant with regard to odor control.

- Micrometeorology on public lands down canyon from the Baca site.

- Characterize and model water resources impacts.

I appologize for the obvious condensations, but I believe the thinking of the workshop participants is amply manifested by these statements. This input will also be used in structuring our technical plan.

If you feel like talking about any of this, or would like to give me some additional input, please don't hesitate to write or call.

Sincerely yours,

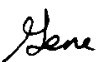

Eugene M. Wewerka

LS-6 Group Leader

Environmental Science Group

EMW : $t j$ 


\section{APPENDIX F}

PARTICIPANTS IN THE LASL/LLL WATER/TERRESTRIAL WORKSHOP

\section{for}

Workshop held at Livermore/Geysers from

April 15-16, 1980

LASL

Life Sciences Division

Gary J. Langhorst

Felix R. Miera

Eugene M. Wewerka

Joel M. Williams
LLL

Environmental Sciences Division

Robert R. Ireland

John J. Koranda

Joseph H. Shinn

Danid1 H. Stuermer

Michael A. Tompkins 